\title{
INNOVATION DYNAMICS AND FINANCIAL STABILITY: A EUROPEAN UNION PERSPECTIVE
}

\author{
Francisco Javier SANTOS-ARTEAGA ${ }^{1 *}$, Madjid TAVANA ${ }^{2,3}$, \\ Celia TORRECILLAS ${ }^{4}$, Debora DI CAPRIO ${ }^{5}$ \\ ${ }^{1}$ Faculty of Economics and Management, Free University of Bolzano, Bolzano, Italy \\ ${ }^{2}$ Business Systems and Analytics Department, Distinguished Chair of Business Analytics, \\ La Salle University, Philadelphia, PA 19141, USA \\ ${ }^{3}$ Business Information Systems Department, Faculty of Business Administration and Economics, \\ University of Paderborn, D-33098 Paderborn, Germany \\ ${ }^{4}$ Departamento de Economía Aplicada, Estructura e Historia, Instituto Complutense de Estudios \\ Internacionales, Universidad Complutense de Madrid, Madrid, Spain \\ ${ }^{5}$ Department of Economics and Management, University of Trento, Trento, Italy
}

Received 05 April 2020; accepted 02 July 2020

\begin{abstract}
We present a formal and empirical framework that links the technological capacity of a country, reflected in its National System of Innovation, with the financial constraints it faces. The paper is divided into two sections. The first one introduces a stochastic growth model based on the relative level of technological development of countries, which determines their productivity and capacity to finance innovation activities. The second section describes the empirical conditioning observed in the innovation outputs of countries determined by their financial constraints and time period relative to the economic crisis of 2008. We classify a panel sample of European Union countries according to their technological development level and find that financial stability constraints negatively affect the less developed ones, a relationship that weakens as their innovation capacity increases. We also observe that financial stability becomes significant among technologically developed countries when reacting to the exogenous shock triggered by the crisis, while laggards remain constrained through the entire 2000-2018 sample period.
\end{abstract}

Keywords: national system of innovation, technological development, innovation dynamics, financial constraints, European stability.

JEL Classification: O31, O33.

\section{Introduction}

The technological infrastructure of a country requires a credit system that facilitates the development of new innovations and the assimilation of negative shocks (Perez, 2004; O'Sullivan, 2005). When analyzing the relationship between finance and innovation, the economic litera-

*Corresponding author. E-mail: FranciscoJavier.Santos-Arteaga@unibz.it 
ture has focused on the importance of the financial structure of countries as a determinant of their capacity to generate new learning opportunities and acquire technological knowledge (Dosi, 1990; Aghion et al., 2005; Mazzucato, 2013). In this regard, the relationship between the financial capabilities of countries and innovation outputs is generally conditioned by economic cycles and exogenous shocks such as the crisis of 2008 (Archibugi \& Fillippeti, 2011; Archibugi et al., 2013).

\section{The financial side}

There is a significant amount of literature connecting innovation and financial constraints (Pellegrino \& Savona, 2017), with papers generally focusing on the identification of the main financial obstacles to innovation (Hall, 2002; Iammarino et al., 2009; Mancusi \& Vezzulli, 2014). This literature could be divided in terms of the barriers for the generation of innovation inputs and outputs, and the obstacles for obtaining external cash flows (Hall, 2008). Most authors agree on the fact that financial constraints reduce the likelihood of firms developing innovations (Savignac, 2008), being these patterns more pronounced in small firms and high technological sectors (Pellegrino \& Savona, 2017).

In particular, innovation capabilities depend on the relation of firms with banks and other financial institutions required to access credit in order to develop, produce, and commercialize new products. The empirical finance literature has shown that credit constraints have a negative impact on innovation and that the characteristics of the national banking system affect innovation through the likelihood that firms face financing constraints (Lorenz \& Pomment, 2017). More precisely, Demirhan and Babacan (2016) illustrated how financial markets and institutions - as significant elements of the innovation ecosystem - affect R\&D expending, university-industry collaborations, and the innovation capacity of countries.

At the macroeconomic level, it has been acknowledged that the structure of the financial system affects how firms behave and, therefore, the degree of successful innovations (Bond et al., 2003). Moreover, as highlighted by Mulkay et al. (2001), the sensibility of firms to the financial system differs depending on the country, a finding that complements the ample macroeconomic evidence illustrating that the development of financial markets is positively correlated with the development of countries (Gorodnichenko \& Schnitzer, 2013).

All in all, the stability of the financial system plays a central role in triggering economic growth through its ability to foster innovations (Ang, 2011; Álvarez et al., 2016). That is, the financial stability of countries favors the development of resilient innovation systems, a particularly useful feature in times of crisis (Fillippeti \& Archibugi, 2011; Archibugi \& Fillippeti, 2012).

\section{The structural side}

Even at the basic textbook level (Aghion \& Howitt, 1999; Barro \& Sala-i-Martin, 2003; Acemoglu, 2008), the economic growth literature has emphasized the fact that the cumulative assimilation of technology requires substantial amounts of investment in both human capital and infrastructures (Jovanovic, 1997; Mukoyama, 2003; Aghion \& Howitt, 2005; Álvarez et al., 2016). The technological infrastructure of a country conditions its capacity to learn 
and innovate since its operational efficiency requires the simultaneous application of the knowledge acquired by its human capital (Furman et al., 2002; Fores \& Camison, 2011; Santos-Arteaga et al., 2017). An extensive amount of empirical evidence describes the infrastructure requirements on which the positive relationship between technology and growth builds (Oliner \& Sichel, 1994; Osei-Bryson \& Ko, 2004; Gorzelany-Dziadkowiec et al., 2019). Constraints generally arise from the technological learning curve through which countries evolve (Dedrick et al., 2003) and their level of development (Dewan \& Kraemer, 2000; Lee et al., 2005).

The National System of Innovation (NSI) can be defined as the diversity of actors that interact to combine resources, opportunities, and policies, and how these interactions enhance the capabilities-building processes that favor innovation in firms, regions, and countries (Freeman, 1987, 1995; Lundvall, 1992, 2007, 2016). Capabilities are identified as drivers for enhancing the NSI in developing countries, while technology gap models underline the role of absorptive capacities and the explicative factors of catching-up processes (Abramovitz, 1986; Lall, 1992; Godin, 2009; Lee \& Kim, 2009; Fagerberg et al., 2007).

One of the main pillars of the NSI is defined by the institutional environment (Dunning \& Lundan, 2008; Witt \& Lewin, 2007), where the financial system plays a vital role. In other words, the financial system could be considered an essential component of the NSI (Van Tilburg, 2009) in both developed and developing countries (Lundvall, 1992; Freeman, 1995). The financial infrastructure of a country, as well as any relevant institutional differences across financial systems, help explaining the impact of financial factors on R\&D investment (Bond et al., 1999; Hall et al., 1999; Mulkay et al. 2001). In this regard, Perez (2002) showed that financial dynamics depend on technological revolutions, with financial capital playing a fundamental role in the generation and expansion of technological revolutions (Mazzucato, 2013).

Finally, we should note that the evolution of the NSI also depends on the social system of countries, especially when dealing with economic inequality and the subsequent social expenditures. To a lesser extent, education and unemployment co-evolve with innovation, acting as either reinforcing or compensatory mechanisms, and should, therefore, be considered as components of the NSI (Lall, 1992; Cozzens \& Kaplinsky, 2009). The interactions described among the innovation, financial, and social systems will be formalized and validated empirically throughout the paper.

\section{Contribution}

We design a stochastic growth model where the level of technological development of country conditions the productive ability of its human capital together with the financial capacity of its firms and the resulting innovation probability. The results obtained highlight the fact that if the economic and financial evolution of countries are conditioned by their level of technological development, then laggards will tend to diverge from the growth path of the innovators while facing increasingly stricter constraints in their capacity to finance innovation activities. Our results also illustrate how the relationship between these variables varies depending on the period of time considered relative to the economic crisis of 2008. 
In particular, we validate our formal model using a dynamic panel of European Union countries encompassing the 2000-2018 period. We observe a negative relationship between financial stability constraints and innovation outputs conditioned by the technological development level of countries. Among the additional results obtained, we must emphasize those describing the varying relationship between inequality and innovation capabilities across differently developed countries - within a common economic area.

Two important remarks follow. First, the formal model presented has been designed to foster convergence across countries in both their levels of technological development and financial capabilities. Second, we do not analyze how the initial differences in technological development levels arise but focus on the capacity of countries to overcome these differences through improvements in total factor productivity and their ability to finance innovationoriented infrastructures.

The paper proceeds as follows. Section 1 formalizes the stochastic evolution of countries and the behavior of firms and consumers/investors within them. Section 2 validates the implications of the model regarding the innovation and financial capacities of the European Union member states through the 2000-2018 period empirically. The last Section concludes and suggests potential extensions. Formal proofs are relegated to the appendices.

\section{The stochastic growth model}

The framework of analysis is simplified through several assumptions designed to foster convergence across unequally developed countries. We assume that the world economy consists of two countries. Generality is not lost by imposing such an assumption, while it simplifies the presentation considerably. Consumers have identical preferences and endowments, eliminating potential divergences arising from demand-pull effects or income differentials. To focus on the divergence caused by technological differences across countries, we assume a fixed exchange rate equal to one together with identical unit prices for the latest technological products.

\subsection{Firms}

Countries have identical endowments of human capital. Every firm within each country is endowed with a fixed amount of $N$ skilled workers, who can be employed in innovative, $n_{n}$, or manufacturing activities, $n_{m}$, with $n_{n}+n_{m}=1$. All workers receive identical $w$ wages. As stated above, product specialization is prevented by taking the price of the most advanced product as the numeraire and fixing the value of the exchange rate to one. In order to simplify the presentation, a unique industrial sector consisting of two firms per country will be analyzed.

The production function of the firms that have not introduced the current innovation is defined as follows:

$$
Y_{m}=\xi A^{1-\alpha} K^{\alpha} n_{m}^{1-\alpha},
$$

where $K$ is the amount of capital, and

$$
\xi=\frac{\lambda^{c}}{\lambda^{*}},
$$


where $\lambda^{*}$ defines the level of development corresponding to the technological frontier and $\lambda^{c}$ is the level attained by the country. To preserve the intuition of standard growth models, $A$ denotes the productivity of the production technology, assumed identical for all firms and across countries. Factor productivity is conditioned by the level of technological development of the national innovation system of the country, $\xi$ (Greenwood et al., 1997). This variable affects both the probability of innovation within a country and the capacity of its firms to exploit the innovations acquired (Furman et al., 2002).

The units of continuous-time are measured on a per innovation basis (Aghion \& Howitt, 1992). Moreover, all firms in both countries will be assumed to gain immediate access to the latest technology. Thus, the quality-adjusted unitary prices per product will be identical across firms, with infinitely elastic demands absorbing the respective production in each country. As a result, profits will be increasing on $\xi$ and the level of total factor productivity, denoted by $\Gamma$.

The production function of a firm after developing an innovation equals

$$
Y_{n}=\Gamma^{2} Y,
$$

with $\Gamma>1, \xi=1$ and $Y=A^{1-\alpha} K^{\alpha} n_{m}^{1-\alpha}$. Firms located in the country where the latest innovation has been introduced to display identical levels of development, namely, $\xi=1$ for both firms. A similar reasoning implies that those firms located in the laggard country are endowed with the same $\xi<1$ value.

We incorporate an immediate catch-up mechanism between countries, with $\xi=1$ for the country generating the next innovation. Thus, a laggard firm introducing an innovation increases its output by $\Delta Y=Y_{n}-Y_{m}=\left(\Gamma^{2}-\xi\right) Y$. Introducing an innovation allows the corresponding firm to increase its output by a factor of $\Gamma$ with respect to that of the current innovator, leading to an increase in output equal to

$$
\frac{\Delta Y}{\Gamma Y}=\frac{Y_{n}-Y_{m}}{\Gamma Y}=\left(\Gamma-\frac{\xi}{\Gamma}\right),
$$

if the firm was located in the laggard country. Since the output of a current innovator equals $Y_{m}=\Gamma Y$, equation (4) implies an increase in productivity of $(\Gamma-1)$. That is, output grows at a rate of $(\Gamma-1)$ per time unit, a standard exponential progression in endogenous growth environments (Aghion \& Howitt, 1992).

\subsection{Optimizing countries}

We consider a unique representative industrial sector with two firms per country, while noting that introducing a countable number of firms per sector (López et al., 2011) would simply complicate the presentation without increasing its generality.

Countries maximize profits by distributing their human capital between innovation and manufacturing activities, while constrained by the corresponding level of technological development:

$$
\Pi(t)=E\left[\int_{t}^{+\infty} e^{-\rho[\tau-t]} \pi\left(n_{m}\right) d \tau\right],
$$


where

$$
\pi\left(n_{m}, n_{n}\right)=\xi A^{1-\alpha} K^{\alpha} n_{m}^{1-\alpha}-w
$$

and $\rho$ stands for the firms' rate of time preference, assumed identical across firms and countries.

The arrival rate of the Poisson process that governs innovations equals

$$
\theta_{\xi}=\frac{\lambda^{c}}{\lambda^{*}} v(\xi) n_{n}^{1-\varphi},
$$

where $(1-\varphi)$ is the labor elasticity in innovation-related activities, assumed higher than the manufacturing-related one, i.e. $\varphi<\alpha$ (Aghion \& Howitt, 2005). The innovation arrival rate is determined by the value of the assets issued by the local firms, $v(\xi) \in[0,1]$, which, at the same time, relates positively to $\xi$ (Filippetti \& Archibugi, 2011).

Innovations are generated via random events increasing the total factor productivity of the firm with respect to that of the current innovator

$$
d\left(\frac{\xi}{\Gamma}\right)=\left(\Gamma-\frac{\xi}{\Gamma}\right) d z_{\xi}
$$

The value of a firm's assets after introducing an innovation increases by a factor of $\alpha_{v}>1$ over that of the current innovator, i.e. $v$,

$$
d v(\xi)=\left[\alpha_{v} v-v(\xi)\right] d z_{\xi}
$$

The evolution of total factor productivity and asset values is conditioned by the level of technological development of the country since the latter determines the stochastic arrival rate, $\theta_{\xi}$, of the $z_{\xi}$ Poisson process.

The optimization problem faced by each country is defined by the following Bellman equation (formal details are provided in Appendix A)

$$
\rho V\left(\frac{\xi}{\Gamma}, v(\xi)\right)=\max _{n_{m}, n_{n}}\left[\pi\left(n_{m}\right)+\theta_{\xi}\left[V\left(\Gamma, \alpha_{v} v\right)-V\left(\frac{\xi}{\Gamma}, v(\xi)\right)\right]\right] .
$$

The optimization problem balances the immediate profits derived from manufacturing, $\pi\left(n_{s m}\right)$, with respect to the potential ones following from innovation-related activities, $\theta_{\xi}\left[V\left(\Gamma, \alpha_{v} v\right)-V\left(\frac{\xi}{\Gamma}, v(\xi)\right)\right]$. The same intuition applies to the first-order conditions when defining the optimal allocation of labor determined by $\xi$

$$
(1-\alpha) \xi A^{1-\alpha} K^{\alpha} n_{m}^{-\alpha}=(1-\phi) \xi v(\xi) n_{n}^{-\phi}\left[V\left(\Gamma, \alpha_{v} v\right)-V\left(\frac{\xi}{\Gamma}, v(\xi)\right)\right] .
$$

Equation (10) equates the marginal productivity of labor in manufacturing with the marginal value increment derived from the Poisson arrival rate when labor is used to innovate. We will consider the following simplified version of Equation (10):

$$
\frac{n_{n}^{\phi}}{n_{m}^{\alpha}}=H\left(\frac{1-\phi}{1-\alpha}\right)\left[V\left(\Gamma, \alpha_{v} v\right)-V\left(\frac{\xi}{\Gamma}, v(\xi)\right)\right] \text { with } H=\frac{v(\xi)}{A^{1-\alpha} K^{\alpha}} .
$$

Equation (11) implies that a substantial increase in factor productivity or asset value gains incentivizes the use of labor in innovative activities relative to manufacturing ones. 


\subsection{Consumers/investors}

Consumers - who also act as investors - are identical in both countries and consume the latest most advanced product, which is supplied at the same price but different productivity rates by the firms in each country. This simplifying assumption allows us to define the maximization problem of consumers in terms of their stochastic budget constraints.

The number of assets owned from the current innovator firms located in the innovator and laggard countries is given by $a_{n}^{n}$ and $\frac{a_{m \mid n}^{m}}{2}$, respectively. In both countries, the value of each asset equals $v$. The income of a consumer when a firm from the innovator country develops the next innovation is equal to

$$
d\left(v_{n} a_{n}^{m}\right)=\left[v a_{n}^{n}+\frac{v a_{m \mid n}^{m}}{2}-v_{n} a_{n}^{m}-v_{m} a_{m}^{m}\right] d t+\left[\alpha_{v} v a_{n}^{m}-v_{n} a_{n}^{m}\right] d z_{n},
$$

Similarly, a stochastic differential equation defines the evolution of the income of a consumer when a firm from the laggard country develops the next innovation

$$
d\left(\frac{v_{m} a_{m}^{m}}{2}\right)=\left[v a_{n}^{n}+\frac{v a_{m \mid n}^{m}}{2}-v_{n} a_{n}^{m}-v_{m} a_{m}^{m}\right] d t+\left[\frac{\alpha_{v} v a_{m}^{m}}{2}-\frac{v_{m} a_{m}^{m}}{2}\right] d z_{m} .
$$

Consumers spend $v_{n} a_{n}^{m}$ in assets from the firm located in the innovator country at a price of $v_{n}$ per share, while $v_{m} a_{m}^{m}$ is spent in assets from both firms in the laggard country at a price of $v_{m}$ per share, with $v_{m}<v_{n}$. For expositional simplicity, we have assumed that consumers divide their purchases equally between both firms in the laggard country.

The simplest formal and notational scenario arises when considering a continuum of industrial sectors indexed by $\omega$. That is, $v a_{n}^{n}+\frac{v a_{m \mid n}^{m}}{2}$ corresponds to $v \int_{0}^{1} a_{n}^{n}(\omega) d \omega+\frac{v}{2} \int_{0}^{1} a_{m \mid n}^{m}(\omega) d \omega$, which represents the income of consumers per period of time derived from the investment choices made in the previous period. In this regard, the homogeneity assumed across consumers in both information and preferences could be relaxed so that the deterministic section of Equations (12) and (13) incorporates failure rates in the investment decisions of consumers.

Innovations are generated at a rate defined by the Poisson processes associated with each country, namely, $z_{n}$ for the innovator and $z_{m}$ for the laggard. Independently of the country, the value of the assets of the firm developing a new innovation increases by $\alpha_{v}(>1)$ times $v$.

The expected income of consumers per unit of time is given by

$$
E[v a]=\mu_{n}\left(\theta_{n}\right) v_{n} a_{n}^{m}+\mu_{m}\left(\theta_{m}\right) \frac{v_{m} a_{m}^{m}}{2},
$$

where $\mu_{i}\left(\theta_{i}\right), i=m, n$, denotes the subjective probability assigned by consumers to the introduction of the next innovation by a firm in the country $i$. We will assume that $\frac{\partial \mu_{i}\left(\theta_{i}\right)}{\partial \theta_{i}}>0$
and $\mu_{m}\left(\theta_{m}\right)+\mu_{n}\left(\theta_{n}\right)=1$. 
The stochastic behavior of the expected income of consumers is therefore defined as follows (refer to Appendix A for additional formal details)

$$
\begin{aligned}
& d\left(\mu_{n}\left(\theta_{n}\right) v_{n} a_{n}^{m}+\mu_{m}\left(\theta_{m}\right) \frac{v_{m} a_{m}^{m}}{2}\right)=\left[v a_{n}^{n}+\frac{v a_{m \mid n}^{m}}{2}-v_{n} a_{n}^{m}-v_{m} a_{m}^{m}\right] d t+ \\
& {\left[\mu_{n}\left(\theta_{n}\right)\left[\alpha_{v} v a_{n}^{m}-v_{n} a_{n}^{m}\right]\right] d z_{n}+\left[\mu_{m}\left(\theta_{m}\right)\left(\frac{\alpha_{v} v a_{m}^{m}}{2}-\frac{v_{m} a_{m}^{m}}{2}\right)\right] d z_{m} .}
\end{aligned}
$$

Equation (15) is used to derive the optimization problem of consumers, determined by the stochastic evolution of their expected income (refer to Appendix A for additional formal details)

$$
\begin{aligned}
& \rho V(E(v a))=\max _{a_{n}^{m}, a_{m}^{m}}\left\{V_{E(v a)}[E(v a)]\left[v a_{n}^{n}+\frac{v a_{m \mid n}^{m}}{2}-v_{n} a_{n}^{m}-v_{m} a_{m}^{m}\right]+\right. \\
& \theta_{n}\left[V\left[\mu_{n}\left(\theta_{n}\right)\left(\alpha_{v} v a_{n}^{m}\right)+\mu_{m}\left(\theta_{m}\right) \frac{v_{m} a_{m}^{m}}{2}\right]-V\left[\mu_{n}\left(\theta_{n}\right) v_{n} a_{n}^{m}+\mu_{m}\left(\theta_{m}\right) \frac{v_{m} a_{m}^{m}}{2}\right]\right]+ \\
& \left.\theta_{m}\left[V\left[\mu_{n}\left(\theta_{n}\right) v_{n} a_{n}^{m}+\mu_{m}\left(\theta_{m}\right)\left(\frac{\alpha_{v} v a_{m}^{m}}{2}\right)\right]-V\left[\mu_{n}\left(\theta_{n}\right) v_{n} a_{n}^{m}+\mu_{m}\left(\theta_{m}\right) \frac{v_{m} a_{m}^{m}}{2}\right]\right]\right\} .
\end{aligned}
$$

The first-order conditions lead to

$$
\begin{aligned}
& \theta_{n}\left(\frac{\mu_{n}\left(\theta_{n}\right) \alpha_{v} v}{\left(1+\mu_{n}\left(\theta_{n}\right)\right) v_{n}}-\frac{\mu_{m}\left(\theta_{m}\right)}{2+\mu_{m}\left(\theta_{m}\right)}\right) V^{\prime}[\Delta E(v a) \mid n]= \\
& \theta_{m}\left(\frac{\mu_{m}\left(\theta_{m}\right) \alpha_{v} v}{v_{m}\left(2+\mu_{m}\left(\theta_{m}\right)\right)}-\frac{\mu_{n}\left(\theta_{n}\right)}{1+\mu_{n}\left(\theta_{n}\right)}\right) V^{\prime}[\Delta E(v a) \mid m],
\end{aligned}
$$

where $V^{\prime}[X]$ denotes the first-order derivative of $V[X]$ relative to the variable $X$. $V^{\prime}[\Delta E(v a) \mid n]$ (respectively $V^{\prime}[\Delta E(v a) \mid m]$ ) corresponds to the marginal value from an increase in the expected income after innovation is introduced by a firm from the innovator (respectively laggard) country.

Equation (17) defines the optimal distribution of investment across the firms located in both countries. In particular, this equation states that the marginal income value derived from a potential innovation developed by a firm from the innovator country must be equal to the one obtained from a firm located in the laggard country. In both cases, the potential increments in marginal value must be weighted by the relative increase in the value of the assets of the corresponding innovator firm. Equation (17) can be rewritten as

$$
\frac{V^{\prime}[\Delta E(v a) \mid n]}{V^{\prime}[\Delta E(v a) \mid m]}=\frac{\theta_{m} v_{n}\left[\alpha_{v} v\left(1+\mu_{n}\left(\theta_{n}\right)\right) \mu_{m}\left(\theta_{m}\right)-v_{m}\left(2+\mu_{m}\left(\theta_{m}\right)\right) \mu_{n}\left(\theta_{n}\right)\right]}{\theta_{n} v_{m}\left[\alpha_{v} v\left(2+\mu_{m}\left(\theta_{m}\right)\right) \mu_{n}\left(\theta_{n}\right)-v_{n}\left(1+\mu_{n}\left(\theta_{n}\right)\right) \mu_{m}\left(\theta_{m}\right)\right]} .
$$

Two brief remarks follow. First, the main results obtained remain qualitatively unmodified if industrial sectors were composed of $N$ firms instead of two. Second, the innovation probability of firms has been defined in terms of the value of their assets while omitting the total amount of funds. This is a pertinent distinction that does not, however, modify the main results obtained. 


\subsection{Structural evolution}

Equations (11) and (18) determine the stochastic evolution of the economic system

$$
\begin{aligned}
& \frac{n_{n}^{\phi}}{n_{m}^{\alpha}}=H\left(\frac{1-\phi}{1-\alpha}\right)\left[V\left(\Gamma, \alpha_{v} v\right)-V\left(\frac{\xi}{\Gamma}, v(\xi)\right)\right], \\
& \frac{V^{\prime}[\Delta E(v a) \mid n]}{V^{\prime}[\Delta E(v a) \mid m]}=\frac{\theta_{m} v_{n}\left[\alpha_{v} v\left(1+\mu_{n}\left(\theta_{n}\right)\right) \mu_{m}\left(\theta_{m}\right)-v_{m}\left(2+\mu_{m}\left(\theta_{m}\right)\right) \mu_{n}\left(\theta_{n}\right)\right]}{\theta_{n} v_{m}\left[\alpha_{v} v\left(2+\mu_{m}\left(\theta_{m}\right)\right) \mu_{n}\left(\theta_{n}\right)-v_{n}\left(1+\mu_{n}\left(\theta_{n}\right)\right) \mu_{m}\left(\theta_{m}\right)\right]} .
\end{aligned}
$$

Equation (PS) accounts for the optimality of the production section of the economy, distributing human capital in terms of its productivity and the potential gains in asset values obtained from an innovation. On the other hand, equation (FS) describes the optimal allocation of investment between countries based on the existing differences in the expected innovation-based income of consumers. The dynamic complementarities arising between the production and financial sections of the model behave as follows:

- the value of the assets issued by the firms within a country - together with and conditioned by its technological development level - determine the proportion of workers allocated to innovative activities;

- this set of variables also determines the corresponding innovation probabilities, which, at the same time, define the expected income of consumers, and, therefore, their investment allocation decisions.

It should be emphasized that the allocation of the assets purchased by consumers can be used to update their value through the inclusion of an additional stochastic differential process. The additional set of equations would increase the complexity of the formal presentation without modifying the main results obtained and has, therefore, been omitted.

The main consequences derived from the interplay between the financial and structural systems of a country are summarized in the following proposition.

Proposition 1.1. The convergence capacity of technological laggards is determined by the section of the cycle through which countries evolve as follows:

(i) Countercyclical scenario: if $\lim _{\xi \rightarrow 0}\left(\frac{\theta_{m}}{v_{m}}\right)=0$ and $V[\cdot]$ is convex, funds flow to the laggard countries to promote innovation. Convergence is constrained by the relative width of the technological gap between countries: the system promotes the equality of productivity and asset values across countries, opposing the emergence of a new

(ii) Procyclical scenario: if $\lim _{\xi \rightarrow 0}\left(\frac{\theta_{m}}{v_{m}}\right)=0$ and $V[\cdot]$ is concave, the flow of funds to the laggard decreases as the technological gap widens, stopping when the limit case is eventually reached.

Note that when $\theta_{i}$ and $v_{i}$ are identical, with $i=n, m$, the potential income gains derived from an innovation taking place within a laggard country are substantially lower in (ii) compared to (i). As a result, if the technological gap between countries remains relatively contained within the countercyclical scenario, convergence may take place, though with a decreasing probability as the gap widens. 
Two final remarks follow. Intermediate scenarios with $\lim _{\xi \rightarrow 0}\left(\frac{\theta_{m}}{v_{m}}\right)>0$ and different quantities of funds flowing to the laggard country can be easily defined and analyzed. Also, even though we have assumed that both countries evolve through the same region of a technological cycle, a sigmoid shaped $V[\cdot]$ could be analyzed, leading to the emergence of multiple equilibria.

\section{Empirical analysis}

The formal model is tested empirically using a panel of European Union data through the period ranging from 2000 to 2018. The following set of hypotheses has been developed to test the validity of the conclusions derived from the formal model:

H1. There is a relationship between the financial capabilities/constraints of countries and the resulting innovation outcomes that depends on the technological development level of countries. We propose the existence of a negative relationship between financial capabilities and innovation results among technological laggards (H1a). This relationship should become positive as the technological development level of the countries increases (H1b).

Our first hypothesis is backed by ample empirical evidence suggesting that financial stability triggers innovation and increases productivity growth (Aghion et al., 2012; Kerr \& Nanda, 2014). However, this relationship may change depending on the period analyzed, with financial constraints having a negative impact on productivity growth and innovation results in times of crisis (Laeven \& Valencia, 2013; Manaresi \& Pierri, 2017; Besley et al., 2018). Our second hypothesis builds on this additional evidence.

H2. The relationship between financial stability constraints and innovation results depends on the period of time being considered. This temporal dimension becomes especially relevant when defined in relation to the economic crisis of 2008. We propose the existence of a persistent negative relationship between financial constraints and innovation among technological laggards (H2a). This relationship should either vanish or become positive in regular times as the technological development level of the countries increases $(\mathrm{H} 2 \mathrm{~b})$.

It will also be necessary to include several control variables accounting for the characteristics of the social structure, the expenditure in research and development, and market dynamism. Each of these factors is represented by its respective indicators and will be operationalized through the corresponding independent variables in the empirical model.

\subsection{Sample and description of the variables}

This section describes the variables and methodological procedures composing the empirical assessment of the formal model developed through the previous sections. The sample panel consists of the 28 European Union member states observed throughout the period 2000-2018. The extension of this timeframe allows us to work with relatively robust approximations of the dynamic trends in country-level science, technology, and innovation systems without facing large amounts of missing data. 
Given the argument that financial stability conditions innovation capacities while constrained by relative technological development levels, countries have been divided across upper and laggard innovation categories using the summary innovation index variable computed by the Innovation Union Scoreboard ${ }^{1}$ (European Commission, 2019). The list of countries analyzed together with their corresponding technological classification is provided in Table B1 within Appendix B.

Table 1 describes the main variables used in our empirical analysis. The dependent variable is given by the summary innovation scoreboard index (INNOV), which acts as a proxy for the quality and strength of the NSI of each country (Archibugi et al., 2013). We also consider patent applications by residents per capita as the dependent variable, which provides a common alternative to capture the innovation output of countries (Ang \& Madsen, 2012).

Table 1. Variable description

\begin{tabular}{|c|c|c|c|}
\hline & Name & Description & Source \\
\hline \multicolumn{4}{|c|}{ Dependent Variable } \\
\hline \multirow[t]{2}{*}{ Innovation } & INNOV & European Innovation Scoreboard & $\begin{array}{l}\text { European Commission, } \\
2020\end{array}$ \\
\hline & Patents & Patents by resident per capita & Worldbank indicators, 2020 \\
\hline \multicolumn{4}{|c|}{ Independent Variables } \\
\hline $\begin{array}{l}\text { Financial } \\
\text { Stability }\end{array}$ & $\begin{array}{l}\text { Financial } \\
\text { Stability }\end{array}$ & $\begin{array}{l}\text { Long-term interest rates refer to } \\
\text { government bonds maturing in ten } \\
\text { years. Rates are mainly determined by } \\
\text { the price charged by the lender, the risk } \\
\text { from the borrower and the fall in the } \\
\text { capital value. }\end{array}$ & OECD dataset, 2020 \\
\hline \multirow[t]{4}{*}{$\begin{array}{l}\text { Social } \\
\text { Structure }\end{array}$} & GINI & $\begin{array}{l}\text { The Gini index measures the extent to } \\
\text { which the distribution of income (or, in } \\
\text { some cases, consumption expenditure) } \\
\text { among individuals or households within } \\
\text { an economy deviates from a perfectly } \\
\text { equal distribution. }\end{array}$ & Worldbank indicators, 2020 \\
\hline & $\begin{array}{l}\text { Social } \\
\text { Expenditure }\end{array}$ & $\begin{array}{l}\text { Social expenditure (\% GDP). Estimates } \\
\text { of net total spending in the main } \\
\text { social policy areas: Old age, Survivors, } \\
\text { Incapacity-related benefits, Health, } \\
\text { Family, Active labor market programs, } \\
\text { Unemployment, Housing, and Other } \\
\text { social policy areas. }\end{array}$ & OECD dataset, 2020 \\
\hline & EDU & School enrollment, secondary (\% net) & Worldbank indicators, 2020 \\
\hline & UNE & Unemployment (\% of labor force) & Worldbank indicators, 2020 \\
\hline $\begin{array}{l}\text { Innovation } \\
\text { inputs }\end{array}$ & $\mathrm{R} \& \mathrm{D}$ & Research and Development (\% GDP) & Worldbank indicators, 2020 \\
\hline $\begin{array}{l}\text { Internal } \\
\text { Dynamism }\end{array}$ & GDPgrowth & GDP growth (annual \%) & Worldbank indicators, 2020 \\
\hline
\end{tabular}

Among the independent variables, long-term interest rates (Financial Stability) are included as a proxy for the financial stability constraints faced by countries (Tylecote, 1994). 
Long-term interest rates are generally used to account for financial stability since they encompass the effects derived from the behavior of risk premia and the issuing of government debt (Aghion et al. 2012, 2019; Popov, 2017). This financial relationship is controlled through several macroeconomic variables describing the social structure of countries: the Gini Index (GINI) - as a measure of inequality, social expenditure, as well as the levels of education (EDU) and unemployment (UNEM) (Cozzens \& Kaplinsky, 2009). In addition, the investment in research and development activities as a percentage of GDP (R\&D) is included as the main indicator of innovation inputs (Günther et al., 2019). Finally, GDP growth is introduced to measure differences in economic dynamism across countries (Álvarez \& Torrecillas, 2020).

Table 2 presents basic descriptive statistics for the entire sample and the groups of upper and laggard innovators. The differences between upper and laggard innovators are evident when considering the main structural variables. Higher innovation levels can be observed among upper relative to laggard innovators, with the latter group displaying higher long-term interest rates. In other words, an increase in the innovation output is associated with lower long-term interest rates, reflecting a more stable financial system. This result is also illustrated in Figure 1 through a dispersion graph describing the relationship between innovation outputs and financial stability.

The data describes a potential negative relationship between the innovation capacity of countries, their unemployment levels and social structures. In other words, upper innovators exhibit lower levels of unemployment and inequality than laggards. Finally, upper innovators display higher expenditures in $\mathrm{R} \& \mathrm{D}$ than laggards. This latter result is also illustrated through a dispersion graph, Figure 2, which describes the relationship between R\&D expenditure and innovation results.

Basic intuition validating the formal results of Proposition 1.1 can be provided through a visual analysis describing the evolution of the main variables within two representative countries such as Germany - for the upper innovators - and Spain - for the laggards. The unemployment, long term interest rates, and GDP growth of Germany and Spain through the 2003-2018 period are presented in Figures 3(a) and 3(b), respectively. The summary in-

Table 2. Summary statistics

\begin{tabular}{|l|c|c|c|c|c|c|}
\hline \multirow{2}{*}{ Variables } & \multicolumn{2}{c|}{ EU28 } & Upper innovators & \multicolumn{2}{c|}{ Laggards } \\
\cline { 2 - 7 } & Mean & Std. Dev. & Mean & Std. Dev. & Mean & Std. Dev. \\
\hline INNOV & 0.43 & 0.16 & 0.59 & 0.09 & 0.31 & 0.08 \\
\hline Patents by resident & 4115 & 9761 & 8351 & 13866 & 1064 & 1883 \\
\hline Financial Stability & 3.90 & 2.41 & 3.15 & 1.71 & 4.81 & 2.79 \\
\hline GINI & 31.47 & 3.66 & 29.59 & 2.78 & 33.02 & 3.58 \\
\hline Social Expenditure & 21.86 & 4.51 & 23.85 & 4.28 & 19.70 & 3.69 \\
\hline UNE & 8.52 & 4.05 & 6.67 & 2.29 & 9.99 & 4.52 \\
\hline EDU & 90.96 & 4.27 & 91.77 & 4.14 & 90.27 & 4.28 \\
\hline R\&D & 1.44 & 0.87 & 2.24 & 0.70 & 0.85 & 0.37 \\
\hline GDP growth & 2.51 & 3.50 & 2.13 & 2.94 & 2.79 & 3.86 \\
\hline
\end{tabular}


novation index of both countries and the corresponding social expenditures are described in Figures 4 and 5, respectively. The evolution of this set of variables demonstrates the structural differences in the capacity of both countries to recover from an exogenous shock.

Note first how the unemployment trends of both countries differ substantially, particularly when reacting to the crisis. In clear contrast with Spain, Germany managed to control the evolution of unemployment after the crisis. Similarly, despite the considerable shock to its GDP growth rate, Germany returned to the positive domain after just one year, while Spain displayed negative growth rates for five years.

The financial side of the economic system highlights the differences in structural capabilities between both countries through the consistent decrease in the long-term German

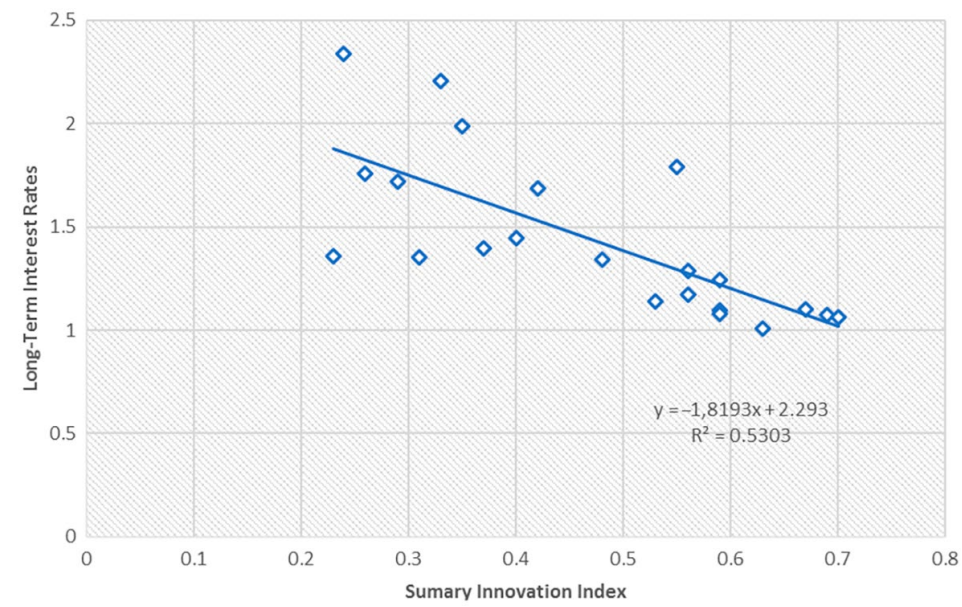

Figure 1. Relationship between innovation and financial capabilities for the entire sample in 2010

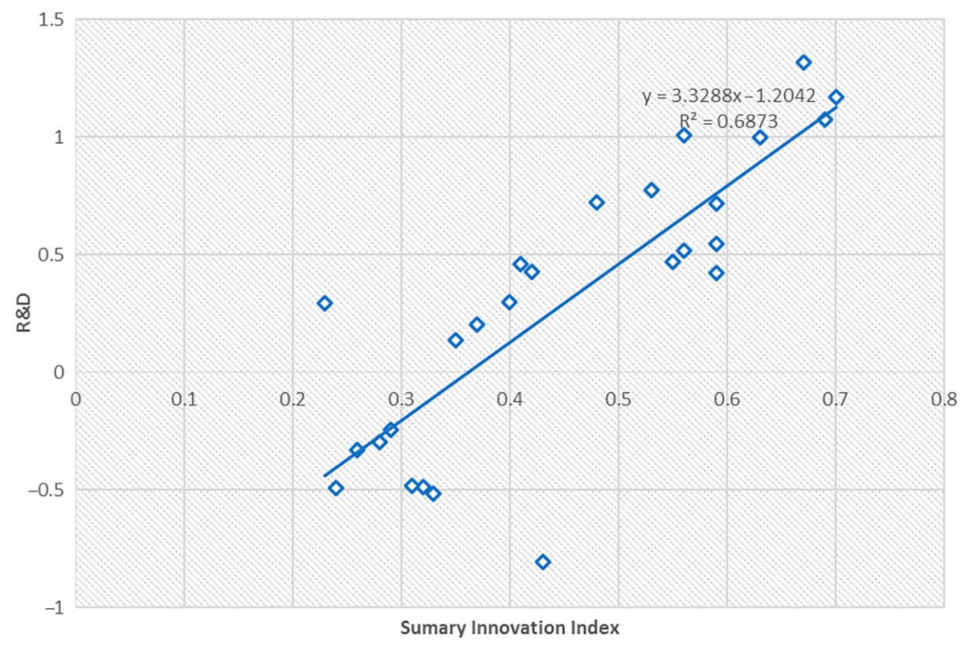

Figure 2. Relationship between R\&D and innovation for the entire sample in 2010 
a) The German case

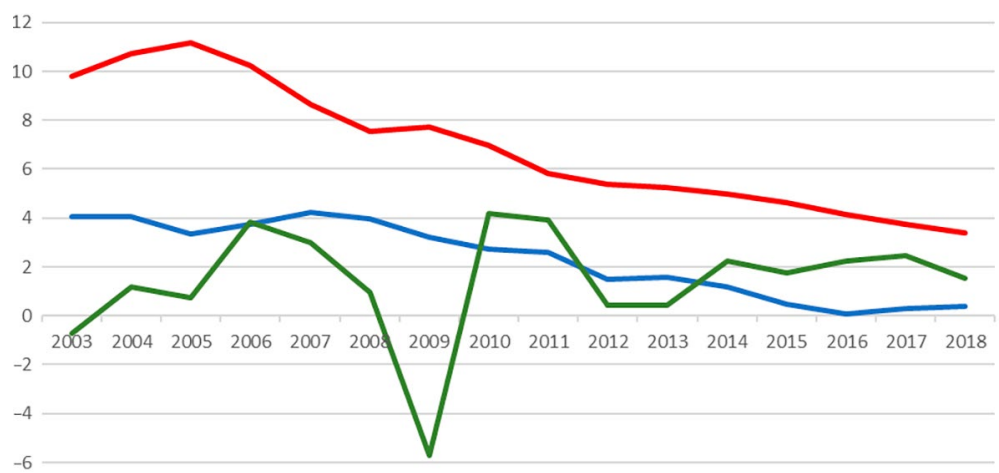

b) The Spanish case

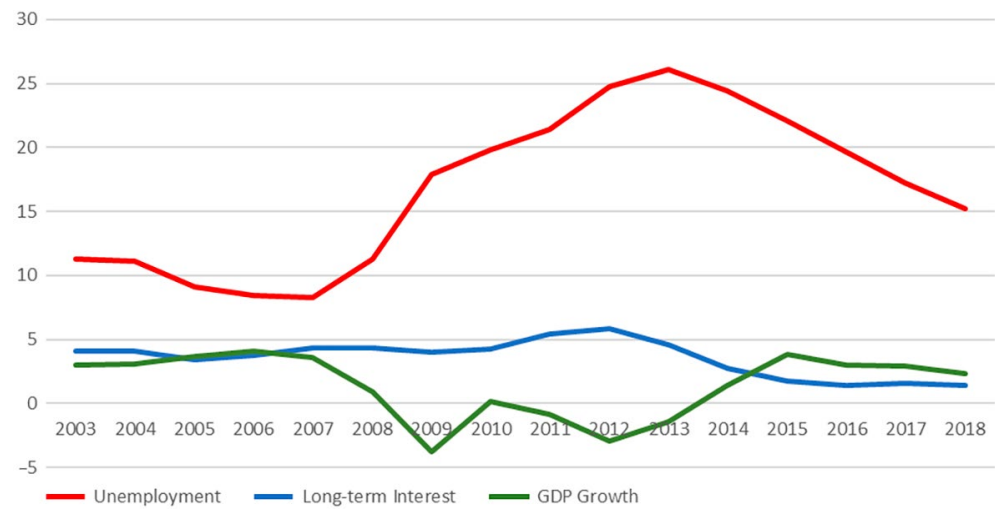

Figure 3. Unemployment, long-term interest rates and per capita GDP growth through the 2003-2018 period

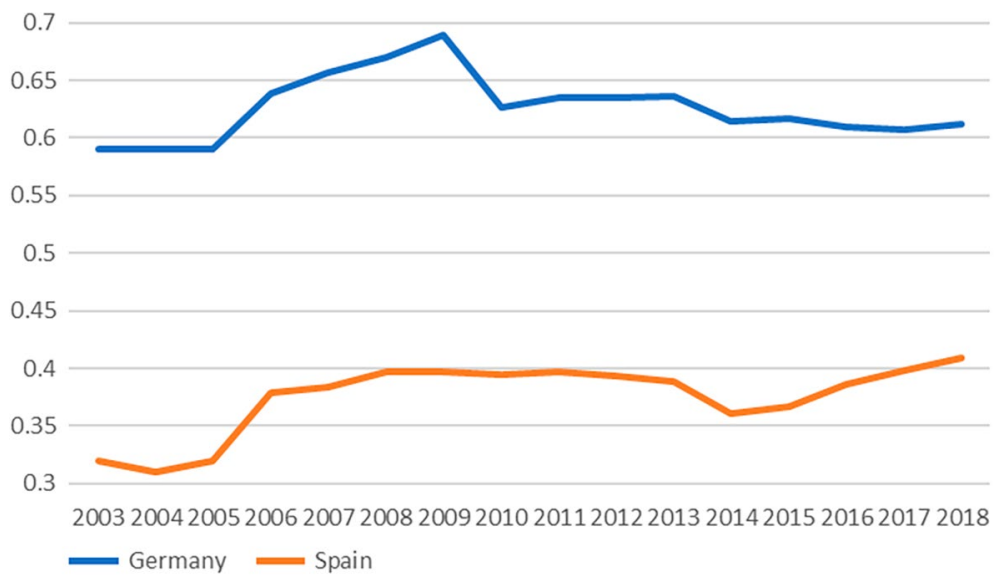

Figure 4. Summary innovation indexes of Germany and Spain through the 2003-2018 period 


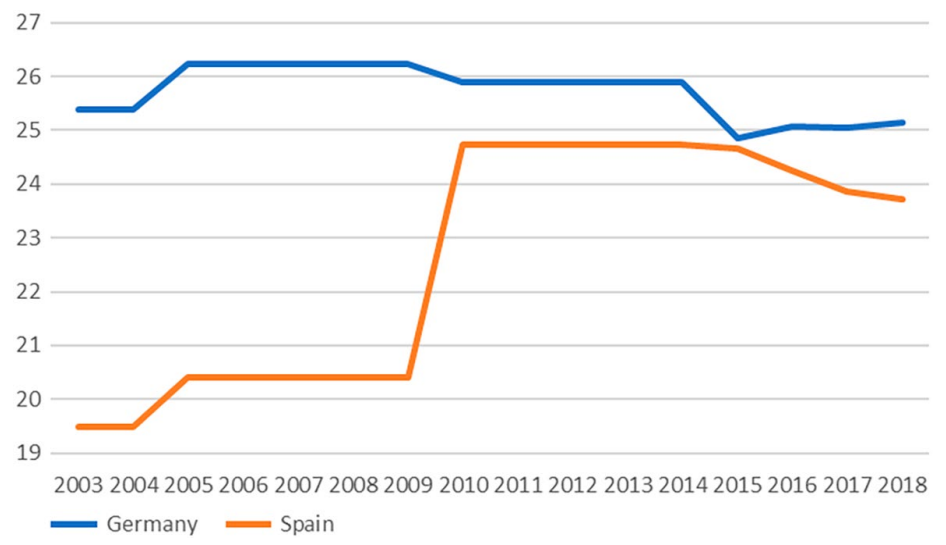

Figure 5. Social expenditures of Germany and Spain through the 2003-2018 period

interest rate, which contrasts with the increase exhibited by the Spanish one through the post-crisis period. This latter trend is complemented by the substantial increase in social expenditure that took place in Spain after the crisis - reaching almost German levels - to ameliorate the negative consequences from the shock.

On the other hand, the summary innovation index of both countries has remained stuck through the post-crisis period, with the differences between their respective values decreasing slightly in the latter years. That is, the initial countercyclical trend exhibited by the summary innovation index and the long-term interest rates was abruptly halted by the crises, resulting in stricter financial stability constraints and structural recovery processes for the laggards.

\subsection{Econometric model}

Given the above empirical intuition, we test the extent to which financial capabilities affect the innovation output of the European Union countries under analysis through the 20002018 period. To capture the dynamics of the process, we implement the Generalized Method of Moments (GMM) for dynamic panel data, where innovation outputs - represented by the innovation scoreboard index and patent applications - are regressed against financial stability and other environmental elements that capture the social structure of countries, innovation inputs and internal market dynamism.

The following two equations, referred to as Model 1 and Model 2, define the relations being estimated

$I N N O V_{i t}=\beta_{0}+\beta_{1}$ Financial Stability $_{i t}+\beta_{2}$ GINI $_{i t}+\beta_{3} E D U_{i t}+\beta_{4} U N E M P_{i t}+$ $\beta_{5} R \& D_{i t}+\beta_{6} \Delta G D P_{i t}+\eta_{s i} \mathrm{v}_{d t}+\varepsilon_{i t}$;

INNOV $_{i t}=\beta_{0}+\beta_{1}$ Financial Stability $_{i t}+\beta_{2}$ Social Expenditure $_{i t}+\beta_{3}$ EDU $_{i t}+\beta_{4} U N E M P_{i t}+$ $\beta_{5} R \& D_{i t}+\beta_{6} \Delta G D P_{i t}+\eta_{s i} \mathrm{v}_{d t}+\varepsilon_{i t}$,

where $I N N O V_{i t}$ represents the innovation output, the subscript " $i$ " identifies each country 
in the sample while " $t$ " represents the time period. Financial Stability ${ }_{i t}$ corresponds to the interest rate of government bonds. $G I N I_{i t}, E D U_{i t}$, and $U N E M P_{i t}$ provide proxies for the social structure of the country. $R D_{i t}$ refers to $\mathrm{R} \& \mathrm{D}$ expenditure as a percentage of GDP. Finally, $\eta_{s i} v_{d t}$ and $\varepsilon_{i t}$ account for specificities of the technique being used and represent individual and time effects as well as the random error term, respectively. The model defined in Equation (20) incorporates Social Expenditure ${ }_{i t}$ in place of EINI $_{i t}$ in order to provide additional empirical evidence regarding the relationship between financial stability and innovation outputs, as well as to validate the results obtained from Model 1.

The correlation matrix among the independent variables composing Models 1 and 2 is presented in Table B2 within Appendix B. This table justifies the selection of the explanatory variables used in the empirical model. Note, in particular, that there is no significant correlation among the variables composing the different sample categories within any of the models.

Two separate sets of estimations have been performed to validate the results of our formal analysis. In the first one, we test our first hypothesis by regressing Models 1 and 2 through the entire period of analysis. As a robustness test, we replicate both models considering patent applications by resident per capita as the dependent variable. In the second set of estimations, we test our second hypothesis by dividing the sample into different time periods relative to the economic crisis, namely, (2000-2007), (2008-2012) and (2013-2018). In both sets of estimations, the data sample has been divided into subsamples determined by the technological development level of countries, corresponding to upper and laggard innovators. The whole sample of European Union countries has also been regressed in all the estimations and used as a reference benchmark.

The interval periods of analysis have not been chosen randomly but are based on an official report issued by the European Commission (2017). In its report, the percentage change in the level of real GDP of the Euro area relative to 2008 is used as a measure of performance for the whole area. The Commission considers the first quarter of 2008 to mark the beginning of the great recession period. Despite an interim recovery period ranging from the second quarter of 2009 to the third quarter of 2011, the European recession starts during this latter quarter, lasting until the first quarter of 2013, which gives place to the official recovery period. A quarter just before the recovery period began, namely, in October 2012, the European Stability Mechanism started to operate.

The use of the dynamic panel data methodology is justified by the inherent endogeneity of the variables and the model (Arellano \& Bond, 1991; Arellano \& Bover, 1995; Roodman, 2012; Labra \& Torrecillas, 2014, 2018). This technique has been applied to test the relationship existing between financial constraints and economic growth since it allows for the use of different instruments in the estimation (Popov, 2017) In particular, it takes into account the path-dependent trajectory of the cumulative process that characterizes innovations (Dosi, 1988; Castellacci, 2008).

\subsection{Empirical results}

The dynamic panel estimations of our first hypothesis are presented in Tables 3 and 4 . The results presented in Table 3 confirm the relationship existing between financial stability con- 
straints and innovation outputs, as suggested in our first hypothesis. Specifically, our findings show that the financial stability variable does not have any effect on the innovation results when the entire sample or the upper innovators are considered. However, it has a negative effect on laggard innovators.

This important result illustrates how, as the price that countries have to pay to obtain funds increases, innovation outputs decrease among laggards. This negative relationship is displayed by countries such as Spain, Portugal, and Greece, which struggle through the initial stages of their innovation processes and are in need of financial resources to develop innovation projects but whose technological development levels fall short of those exhibited by the upper innovators. Moderate innovators do not display this type of relationship. The use of funds for purposes other than innovative activities within a mildly developed technological infrastructure provides an explanation for this result. Upper innovators do not display a significant relationship between both variables, that is, technologically developed countries do not exhibit difficulties financing their innovations and obtaining positive results.

Table 3. Estimation results: innovation scoreboard index as dependent variable

\begin{tabular}{|c|c|c|c|c|c|c|}
\hline & EU28 & $\begin{array}{c}\text { Upper } \\
\text { Innovators }\end{array}$ & Laggards & EU28 & $\begin{array}{l}\text { Upper } \\
\text { Innovators }\end{array}$ & Laggards \\
\hline & \multicolumn{3}{|c|}{ (M1) } & \multicolumn{3}{|c|}{ (M2) } \\
\hline \multirow[t]{2}{*}{ Financial Stability } & 0.011 & -0.007 & $-0.032^{\star * *}$ & -0.015 & -0.008 & $-0.055^{\star * *}$ \\
\hline & $(0.016)$ & $(0.014)$ & $(0.009)$ & $(0.012)$ & $(0.008)$ & $(0.010)$ \\
\hline \multirow[t]{2}{*}{ GINI } & 0.009 & 0.015 & $-0.002^{*}$ & & & \\
\hline & $(0.012)$ & $(0.016)$ & $(0.001)$ & -0.020 & 0.020 & $0.364^{\star * *}$ \\
\hline Social Expenditure & & & & $(0.156)$ & $(0.074)$ & $(0.115)$ \\
\hline \multirow[t]{2}{*}{ EDU } & 0.390 & 0.176 & 0.090 & -0.601 & 0.233 & -0.508 \\
\hline & $(0.366)$ & $(0.504)$ & $(0.210)$ & $(0.553)$ & $(0.331)$ & $(0.426)$ \\
\hline \multirow[t]{2}{*}{ UNEMP } & 0.033 & -0.008 & 0.039 & -0.034 & -0.006 & -0.022 \\
\hline & $(0.088)$ & $(0.045)$ & $(0.012)$ & $(0.048)$ & $(0.020)$ & $(0.021)$ \\
\hline \multirow[t]{2}{*}{$\mathrm{R} \& \mathrm{D}$} & $0.430^{* * *}$ & $0.135^{*}$ & $0.136^{\star * *}$ & $0.223^{* * *}$ & $0.143^{\star * *}$ & -0.024 \\
\hline & $(0.143)$ & $(0.075)$ & $(0.028)$ & $(0.079)$ & $(0.049)$ & $(0.038)$ \\
\hline \multirow[t]{2}{*}{ GDPgrowth } & $-0.096^{*}$ & $-0.030^{\star}$ & -0.024 & -0.009 & $-0.028^{*}$ & $-0.028^{\star}$ \\
\hline & $(0.057)$ & $(0.016)$ & $(0.010)$ & $(0.015)$ & $(0.015)$ & $(0.017)$ \\
\hline \multirow[t]{2}{*}{ _cons } & -1.566 & -0.637 & 0.018 & 3.270 & -0.542 & 1.716 \\
\hline & $(1.961)$ & $(2.636)$ & $(0.926)$ & $(2.394)$ & $(1.390)$ & $(1.867)$ \\
\hline $\operatorname{Ar}(2)$ & -1.37 & -1.60 & -0.99 & -0.64 & -1.59 & -0.45 \\
\hline Hansen. Pro $>$ Chi2 & 0.235 & 0.136 & 0.32 & 0.149 & 0.525 & 0.26 \\
\hline Instruments & 10 & 10 & 10 & 16 & 16 & 10 \\
\hline Observations & 269 & 165 & 109 & 294 & 184 & 117 \\
\hline
\end{tabular}

Note: ${ }^{\star *} \mathrm{p}<0.01,{ }^{\star *} \mathrm{p}<0.05,{ }^{\star} \mathrm{p}<0.1$. 
The financial constraints faced by the laggards and their lack of significance among upper innovators are validated for Models 1 and 2. Therefore, we can confirm our first hypothesis (H1) for both groups of counties, namely, financial stability constraints lose significance as the level of technological development increases.

Regarding our control variables within Model 1, the inequality index accounting for the social system exhibits a negative relationship among laggards, while it is not a significant determinant of innovation outputs among upper innovators. The performance of innovationrelated activities within the latter group of countries does not require draining the quality of their social systems in order to generate technological outputs. In this regard, upper innovators with a developed social system do not exhibit significant effects on their innovation results. It is the funding required through the transition phase what may constitute a drawback for the countries involved.

As intuitively illustrated through the cases of Germany and Spain, the increment in inequality taking place after an exogenous shock stagnates the innovation capacities of countries, leading laggards to a more precarious structural situation and requiring the use of resources for social expenditure that were previously allocated elsewhere. Note, however, how in the case of Spain, the slight increase of the innovation index through the final sample periods coincides with an increase in GDP growth and a slight decrease of social expenditure, reversing the trend observed immediately after the crisis.

All countries experience a decrease in GDP growth during the crisis period, but its posterior evolution differs substantially across upper and laggard innovators. The innovation outputs of both groups of countries are relatively resilient to negative shocks. Note, for instance, how the Spanish innovation index remains stable through the periods of negative GDP growth but improves as GDP starts growing after the crisis. This evolution contrasts with the behavior of the German innovation index, which remains stagnated as growth starts recovering after the initial shock.

Model 2 complements these results, with social expenditure displaying a significant positive relationship among laggards. $\mathrm{R} \& \mathrm{D}$ exhibits a positive effect for all the subsamples analyzed, except for laggard innovators within Model 2, where it is not significant. The substantial significant increase in the effect of social expenditure may be considered as a justification for this result. Finally, as suggested by the argument developed in the previous paragraph, GDP growth tends to be negative and significant for both groups of countries across models. Note also that education and unemployment do not affect innovation outputs in any of the country subsamples or models analyzed.

As a robustness test, we replicate Models 1 and 2 using patent applications by resident per capita as the dependent variable. The corresponding results are presented in Table 4. The estimations obtained to validate the findings reported in Table 3. We observe a negative relationship between financial stability constraints and innovation results for the laggards. However, in this setting, the relationship becomes positive for the group of upper innovators, reinforcing the argument put forward in our first hypothesis.

Regarding the social structure controls, only social expenditure remains positive and significant among laggards in the second model. We should emphasize the positive and significant relationship of $\mathrm{R} \& \mathrm{D}$ expenditure for the upper innovators, a variable that is not sig- 
nificant among the laggards. In other words, additional investment in R\&D activities does not necessarily lead to a larger number of patents among laggard countries, a constraint relaxed as the technological development level of countries increases. Finally, given the resilience displayed by their innovation indexes, GDP growth relates negatively and significantly to patents for the group of laggard countries.

The next set of estimations tests our second hypothesis by analyzing the relationship between innovation and financial capabilities through different time periods relative to the economic crisis. Table 5 describes the behavior of the variables through the periods before (2000-2007), during (2008-2012), and after (2013-2018) the crisis. The estimations performed to account for the entire sample (Table 5.1), the upper innovator countries (Table 5.2), and the laggard ones (Table 5.3).

As intuition suggests, when considering the entire sample of European Union countries, our estimations show that financial stability constraints relate negatively to innovation outputs during the post-crisis period but are not significant through the previous periods.

Table 4. Estimation results: patents as dependent variable

\begin{tabular}{|c|c|c|c|c|c|c|}
\hline & EU28 & $\begin{array}{c}\text { Upper } \\
\text { Innovators }\end{array}$ & Laggards & EU28 & $\begin{array}{c}\text { Upper } \\
\text { Innovators }\end{array}$ & Laggards \\
\hline & \multicolumn{3}{|c|}{ (M1) } & \multicolumn{3}{|c|}{ (M2) } \\
\hline \multirow[t]{2}{*}{ Financial Stability } & -0.006 & $0.178^{\star \star}$ & -0.118 & 0.051 & $0.261^{*}$ & $-0.453^{\star}$ \\
\hline & $(0.159)$ & $(0.089)$ & $(0.186)$ & $(0.153)$ & $(0.151)$ & $(0.263)$ \\
\hline \multirow[t]{2}{*}{ GINI } & 0.101 & -0.028 & 0.002 & & & \\
\hline & $(0.133)$ & $(0.143)$ & $(0.063)$ & & & \\
\hline \multirow[t]{2}{*}{ Social expenditure } & & & & 0.005 & 0.226 & $6.364^{\star}$ \\
\hline & & & & $(1.627)$ & $(0.284)$ & $(3.364)$ \\
\hline \multirow[t]{2}{*}{ EDU } & -2.207 & -4.582 & 1.640 & -2.396 & 1.247 & 7.276 \\
\hline & $(2.820)$ & $(4.238)$ & $(4.752)$ & $(5.063)$ & $(2.932)$ & $(4.596)$ \\
\hline \multirow[t]{2}{*}{ UNEMP } & -0.504 & 0.353 & -0.035 & 0.041 & -2.444 & -0.793 \\
\hline & $(0.707)$ & $(0.741)$ & $(0.246)$ & $(0.398)$ & $(4.472)$ & $(0.489)$ \\
\hline \multirow[t]{2}{*}{$\mathrm{R} \& \mathrm{D}$} & $0.944^{\star}$ & $1.149^{\star \star}$ & 0.301 & $1.344^{\star}$ & $2.831^{\star \star}$ & -1.828 \\
\hline & $(0.535)$ & $(0.490)$ & $(0.424)$ & $(0.711)$ & $(1.278)$ & $(1.460)$ \\
\hline \multirow[t]{2}{*}{ GDPgrowth } & $-0.347^{\star}$ & -0.076 & $-0.413^{\star *}$ & $-0.310^{\star}$ & -0.918 & $-0.851^{\star * *}$ \\
\hline & $(0.178)$ & $(0.214)$ & $(0.167)$ & $(0.179)$ & $(0.818)$ & $(0.272)$ \\
\hline \multirow[t]{2}{*}{ _cons } & -0.519 & 11.459 & -15.701 & 1.972 & -2.915 & $-56.871^{\star \star}$ \\
\hline & $(11.429)$ & $(17.289)$ & $(20474)$ & $(23.133)$ & $(22.347)$ & $(24.201)$ \\
\hline $\operatorname{Ar}(2)$ & -1.32 & -0.58 & -1.50 & -1.41 & -0.29 & 0.27 \\
\hline Hansen. Pro $>$ Chi2 & 0.808 & 0.66 & 0.729 & 0.322 & 0.795 & 0.910 \\
\hline Instruments & 13 & 13 & 13 & 16 & 13 & 10 \\
\hline Observations & 248 & 144 & 106 & 281 & 163 & 118 \\
\hline
\end{tabular}

Note: ${ }^{\star \star *} \mathrm{p}<0.01,{ }^{\star *} \mathrm{p}<0.05,{ }^{\star} \mathrm{p}<0.1$. 
When the samples are divided according to the technological development level of countries, financial stability constraints became negative and significant for the upper innovator countries through the crisis period. Laggards exhibit a negative and significant relationship that prevails throughout the entire sample period. Thus, laggards face considerable difficulties financing their innovations during regular economic periods, a trend reinforced by a large economic shock to the global system such as the crisis. This tendency is reversed among upper innovators after assimilating the shock, as predicted by our formal model.

Table 5. Results relative to the economic crisis period

Table 5.1. European Union

\begin{tabular}{|c|c|c|c|c|c|c|}
\hline & \multicolumn{2}{|c|}{ EU28 2000-2007 } & \multicolumn{2}{|c|}{ EU28 2008-2012 } & \multicolumn{2}{|c|}{ EU28 2012-2013 } \\
\hline & (M1) & (M2) & (M1) & (M2) & (M1) & (M2) \\
\hline \multirow[t]{2}{*}{ Financial Stability } & 0.011 & 0.030 & -0.060 & -0.014 & $-0.042^{\star * *}$ & $-0.052^{\star * *}$ \\
\hline & $(0.098)$ & $(0.107)$ & $(0.037)$ & $(0.030)$ & $(0.012)$ & $(0.019)$ \\
\hline \multirow[t]{2}{*}{ GINI } & $-0.012^{\star * \star}$ & & 0.000 & & 0.004 & \\
\hline & $(0.004)$ & & $(0.014)$ & & $(0.008)$ & \\
\hline \multirow[t]{2}{*}{ Social Expenditure } & & $0.494^{* *}$ & & -0.050 & & $-0.480^{\star * *}$ \\
\hline & & $(0.240)$ & & $(0.229)$ & & $(0.134)$ \\
\hline \multirow[t]{2}{*}{ EDU } & -0.363 & -0.061 & 1.406 & 0.856 & 0.517 & 0.161 \\
\hline & $(0.885)$ & $(0.993)$ & $(0.913)$ & $(0.904)$ & $(0.449)$ & $(0.712)$ \\
\hline \multirow[t]{2}{*}{ UNEMP } & -0.029 & -0.054 & -0.051 & -0.021 & -0.009 & 0.062 \\
\hline & $(0.045)$ & $(0.095)$ & $(0.049)$ & $(0.060)$ & $(0.041)$ & $(0.045)$ \\
\hline \multirow[t]{2}{*}{$\mathrm{R} \& \mathrm{D}$} & $0.278^{* * *}$ & $0.250^{* *}$ & $0.252^{\star * *}$ & $0.306^{\star * *}$ & $0.246^{\star * \star}$ & $0.273^{* * *}$ \\
\hline & $(0.050)$ & $(0.127)$ & $(0.054)$ & $(0.071)$ & $(0.042)$ & $(0.086)$ \\
\hline \multirow[t]{2}{*}{ GDP growth } & $0.296^{* *}$ & $0.214^{*}$ & $-0.035^{\star \star}$ & -0.032 & $-0.132^{*}$ & $-0.327^{\star \star}$ \\
\hline & $(0.122)$ & $(0.147)$ & $(0.015)$ & $(0.040)$ & $(0.078)$ & $(0.164)$ \\
\hline \multirow[t]{2}{*}{ _cons } & 1.546 & -1.418 & -5.683 & -3.208 & -1.698 & 1.938 \\
\hline & $(3.825)$ & $(5.225)$ & $(3.950)$ & $(4.454)$ & $(1.874)$ & $(3.149)$ \\
\hline $\operatorname{Ar}(2)$ & -0.07 & -0.990 & -1.010 & 0.190 & -1.84 & -0.38 \\
\hline Hansen prob $>$ Chi2 & 0.280 & 0.616 & 0.571 & 0.840 & 0.248 & 0.930 \\
\hline Instruments & 15 & 15 & 15 & 15 & 15 & 11 \\
\hline Observations & 87 & 113 & 72 & 72 & 74 & 79 \\
\hline
\end{tabular}

Table 5.2. Upper innovators

\begin{tabular}{|l|c|c|c|c|c|c|}
\hline \multirow{2}{*}{} & \multicolumn{2}{|c|}{ Upper 2000-2007 } & \multicolumn{2}{c|}{ Upper 2008-2012 } & \multicolumn{2}{c|}{ Upper 2013-2018 } \\
\cline { 2 - 7 } & $(\mathrm{M} 1)$ & $(\mathrm{M} 2)$ & $(\mathrm{M} 1)$ & $(\mathrm{M} 2)$ & $(\mathrm{M} 1)$ & $(\mathrm{M} 2)$ \\
\hline Financial Stability & 0.005 & -0.137 & $-0.138^{\star}$ & $-0.065^{\star}$ & -0.018 & 0.006 \\
\hline & $(0.097)$ & $(0.116)$ & $(0.072)$ & $(0.036)$ & $(0.015)$ & $(0.015)$ \\
\hline GINI & 0.006 & & 0.012 & & $0.016^{\star \star}$ & \\
\hline & $(0.013)$ & & $(0.011)$ & & $(0.008)$ & \\
\hline Social expenditure & & -0.115 & & -1.852 & & -0.047 \\
\hline & & $(0.200)$ & & $(3.213)$ & & $(0.131)$ \\
\hline
\end{tabular}


End of Table 5.2

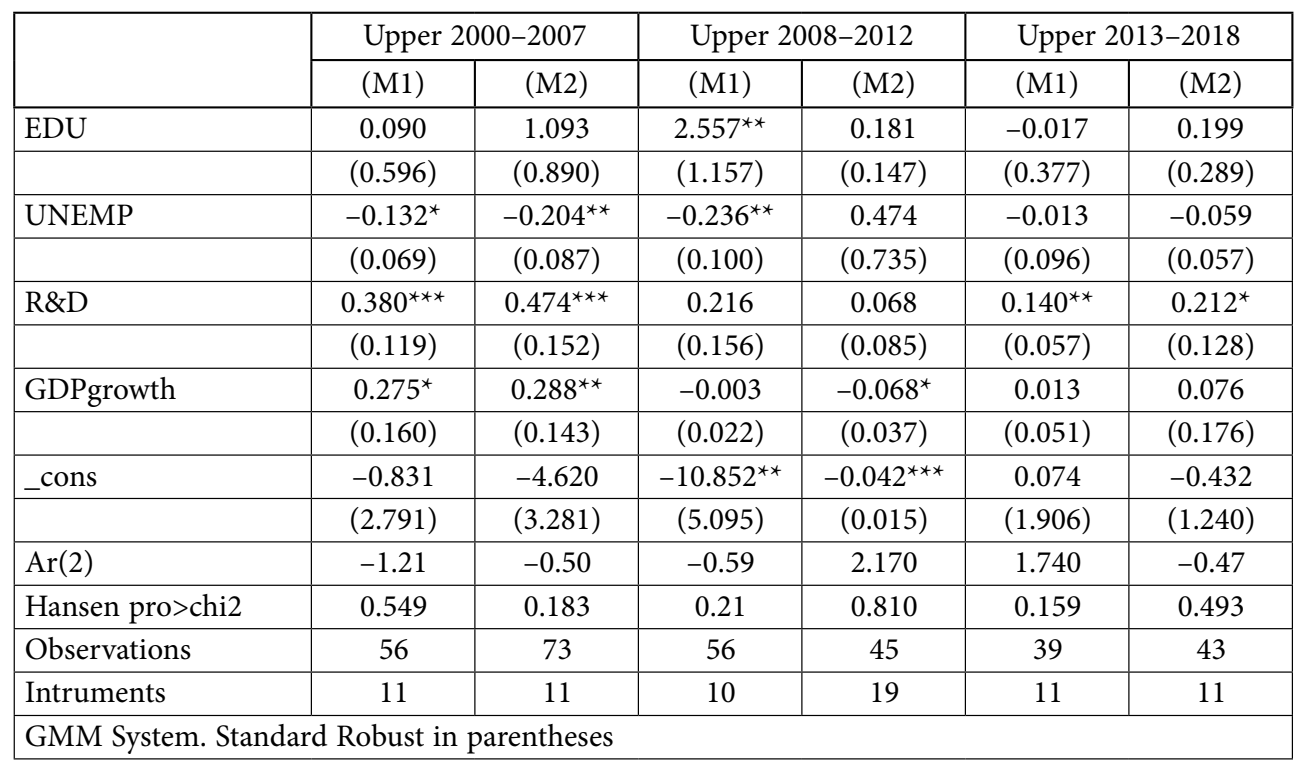

Table 5.3. Laggards

\begin{tabular}{|c|c|c|c|c|c|c|}
\hline & \multicolumn{2}{|c|}{ Laggards 2000-2007 } & \multicolumn{2}{|c|}{ Laggards 2008-2012 } & \multicolumn{2}{|c|}{ Laggards 2013-2018 } \\
\hline & (M1) & (M2) & (M1) & (M2) & (M1) & (M2) \\
\hline \multirow[t]{2}{*}{ Financial Stability } & -0.076 & $-0.099^{\star * *}$ & $-0.067^{\star \star}$ & $-0.120^{* * *}$ & $-0.042^{\star *}$ & $-0.040^{\star \star *}$ \\
\hline & $(0.059)$ & $(0.026)$ & $(0.028)$ & $(0.038)$ & $(0.018)$ & $(0.009)$ \\
\hline \multirow[t]{2}{*}{ GINI } & $-0.010^{* *}$ & & $-0.003^{*}$ & & 0.002 & \\
\hline & $(0.004)$ & & $(0.002)$ & & $(0.007)$ & \\
\hline \multirow[t]{2}{*}{ Social Expenditure } & & $0.191^{\star}$ & & 0.037 & & 0.058 \\
\hline & & $(0.107)$ & & $(0.135)$ & & $(0.108)$ \\
\hline \multirow[t]{2}{*}{ EDU } & -0.329 & -0.170 & -0.115 & -0.305 & -0.058 & 0.650 \\
\hline & $(0.432)$ & $(0.431)$ & $(0.139)$ & $(0.407)$ & $(0.704)$ & $(0.779)$ \\
\hline \multirow[t]{2}{*}{ UNEMP } & 0.025 & $-0.016^{\star *}$ & 0.015 & -0.005 & 0.016 & -0.005 \\
\hline & $(0.043)$ & $(0.008)$ & $(0.015)$ & $(0.016)$ & $(0.019)$ & $(0.023)$ \\
\hline \multirow[t]{2}{*}{$\mathrm{R} \& \mathrm{D}$} & $0.228^{\star \star}$ & $0.097^{\star *}$ & $0.168^{\star * *}$ & 0.079 & $0.121^{\star * \star}$ & $0.090^{*}$ \\
\hline & $(0.098)$ & $(0.043)$ & $(0.019)$ & $(0.069)$ & $(0.033)$ & $(0.053)$ \\
\hline \multirow[t]{2}{*}{ GDPgrowth } & $0.249^{*}$ & $0.244^{* * *}$ & -0.006 & $-0.034^{\star * \star}$ & $-0.120^{\star *}$ & $-0.228^{\star \star}$ \\
\hline & $(0.134)$ & $(0.033)$ & $(0.004)$ & $(0.011)$ & $(0.050)$ & $(0.109)$ \\
\hline \multirow[t]{2}{*}{ _cons } & 1.476 & -0.021 & $1.060^{*}$ & 1.897 & 0.849 & -2.093 \\
\hline & $(1.624)$ & $(2.167)$ & $(0.639)$ & $(1.455)$ & (3.037) & $(3.154)$ \\
\hline $\operatorname{Ar}(2)$ & 0.320 & -0.220 & 0.09 & -1.170 & -1.22 & -0.64 \\
\hline Hansen Prob $>$ Chi2 & 0.679 & 0.930 & 0.950 & 0.860 & 0.579 & 0.900 \\
\hline Instruments & 11 & 11 & 10 & 11 & 11 & 11 \\
\hline Observations & 31 & 38 & 34 & 27 & 35 & 36 \\
\hline
\end{tabular}

Note: ${ }^{* *} \mathrm{p}<0.01,{ }^{* *} \mathrm{p}<0.05,{ }^{\star} \mathrm{p}<0.1$. 
The social structure of the sample displays a negative relationship between the inequality index and the innovation outputs through the pre-crisis period. Moreover, social expenditure is positive and significant for this period but negative after the crisis. That is, the increment in social expenditure to ameliorate the effects of the crisis imposes a burden on the innovation capacity of countries. Upper innovators display a positive and significant GINI value after the crisis, with inequality increasing to foster technological development. Laggards exhibit a negative inequality trend through the 2000-2007 and 2008-2012 periods, complemented via a positive social expenditure effect before the crisis. Thus, laggards were managing to develop technologically while decreasing inequality, reinforcing the capacity of their structural systems to assimilate exogenous shocks - to a certain extent - while preserving social equality.

The control variable accounting for R\&D expenditure is positive and significant for the whole sample through the entire estimation period. This is also the case for upper and laggard innovators, with exceptions arising during the crisis period - where these effects vanish. The structural adjustments required by the techno-economic system as a response to the crisis can justify the existence of such exceptions. That is, the technological infrastructures of these countries are sufficiently developed to withstand the structural adjustments triggered by the crisis, even if these require diverting investment away from their R\&D activities.

GDP growth behaves as expected when considering the whole sample; namely, it is positive through the pre-crisis period and negative afterward. Upper and laggard innovators display similar trends, validating the description provided through the analysis of Tables 3 and 4. In addition, unemployment is negative and significant before and during the crisis across upper innovators, an effect that weakens significantly among laggards. Thus, unemployment decreases when fostering innovation during regular economic periods, an effect that gains consistency as the technological base of the country develops.

\subsection{Policy implications}

Analyzing the policy implications derived from the current framework requires considering simultaneously formal, and empirical features of the countries studied. The empirically illustrated financial stability and structural constraints prevailing through the period analyzed among laggards, together with the inequality and growth problems faced by the upper innovators, complement the formal findings summarized in Proposition 1.1 and intuitively described through Section 2.1. That is, within the convergence-prone countercyclical scenario - where all countries evolve through the convex section of the technological cycle the innovation probability of the laggards tends to decrease even if they continue to receive funds. Thus, when evolving through a divergence-prone procyclical scenario, the lack of appropriate funding reflected in the stricter long-term interest constraints faced by the laggards worsens their structural problems, as illustrated empirically in the aftermath of the crisis.

The divergent process can be counteracted via direct transfers of capital, though these may not suffice to eliminate the existing technological differences (OECD, 2012). Note also that, given their unrestricted access to technology, we have assumed that counties evolve through a common phase of the technological cycle. However, if the most developed countries move to a convex section of the cycle while laggards continue to evolve through the concave one, capital must be transferred directly to foster growth among the laggards. 
This type of transferences may weaken the incentives of the upper innovators to incur the risks inherent to the development of innovations unless compensated by the laggards. The widening of the technological differences arising within this latter group of countries would intensify the negative outcomes following from the corresponding structural (and financial) inequalities, as recognized - to a certain degree - by the European Commission (2010) at the time. Thus, a common innovation policy, including innovation incentives for the upper innovators and distributional ones for the laggards, arises as to the most viable option when considering the long-term stability of a common economic system.

\section{Conclusions and extensions}

The formal framework introduced in the paper aims at reducing the size of the technological gap existing between innovator and laggard countries. To this end, assumptions such as the immediate convergence of technological development levels and asset values after an innovation is developed by one of the firms within a country were introduced. Clearly, relaxing these assumptions so that improvements are determined by the level of technological development of the country would considerably weaken the incentives of laggards to innovate. Similar effects would follow from the emergence of assimilation frictions when adapting the technology acquired to the local system.

Note also that we have not considered the existence of unskilled labor so as to prevent the resulting frictions in human capital allocation from weakening the convergence incentives of laggards further. The unemployment variable introduced in the empirical section of the paper provides some intuition in this respect, with laggards displaying the main consequences from human capital misallocation in the aftermath of the crisis period.

The formal model can be modified to incorporate multiple industrial sectors and allow for countries to specialize by the output sector, adjusting the innovation probability on a sectoral or industrial basis. A direct implication would be the ability of the resulting framework to account for partial convergence processes together with the potential complementarities arising across different industries. From an empirical viewpoint, micro-level data describing the performance of industrial clusters could be used to validate the formal results.

We conclude by noticing the structural similarities existing between the exogenous shock caused by the economic crisis of 2008 and the current one caused by the Covid-19 pandemic. That is, the (expected) consequences for the innovation and financial systems of upper and laggard innovators should be similar to the ones described in the current paper, with convergence processes being halted and divergent scenarios arising as the structural stability of the laggards weakens relative to that of the most technologically advanced countries.

\section{Acknowledgments}

This work was supported by the Open Access Publishing Fund of the Free University of Bozen-Bolzano. 


\section{References}

Abramovitz, M. (1986). Catching up, forging ahead, and falling behind. The Journal of Economic History, 46(02), 385-406. https://doi.org/10.1017/S0022050700046209

Acemoglu, D. (2008). Introduction to modern economic growth. Princeton University Press.

Aghion, P., Askenazy, P., Berman, N., Cette, G., \& Eymard, L. (2012). Credit constraints and the cyclicality of R\&D investment: Evidence from France. Journal of the European Economic Association, 10(5), 1001-1024. https://doi.org/10.1111/j.1542-4774.2012.01093.x

Aghion, P., Bergeaud, A., Cette, G., Lecat, R., \& Maghin, H. (2019). The inverted-u relationship between credit access and productivity growth. Economica, 86, 1-31. https://doi.org/10.1111/ecca.12297

Aghion, P., \& Howitt, P. (1992). A model of growth through creative destruction, Econometrica, 60, 323-351. https://doi.org/10.2307/2951599

Aghion, P., \& Howitt, P. (1999). Endogenous growth theory. MIT Press.

Aghion, P., \& Howitt, P. (2005). Growth with quality-improving innovations: an integrated framework. in P. Aghion \& S. Durlauf (Eds.), Handbook of economic growth, (pp. 67-110). Elsevier. https://doi.org/10.1016/S1574-0684(05)01002-6

Aghion, P., Howitt, P., \& Mayer-Foulkes, D. (2005). The effect of financial development on convergence: theory and evidence, Quarterly Journal of Economics, 120, 173-222. https://doi.org/10.1162/qjec.2005.120.1.173

Álvarez, I., Di Caprio, D., \& Santos-Arteaga, F. J. (2016). Technological assimilation and economic growth in times of crisis: on the evolution of the Baltic states. Technological and Economic Development of Economy, 22(2), 254-273. https://doi.org/10.3846/20294913.2015.1033663

Álvarez, I., \& Torrecillas, C. (2020). Interactive learning processes and mergers and acquisitions in national systems of innovation. Transnational Corporations Review, 12, 63-81. https://doi.org/10.1080/19186444.2020.1735782

Ang, J. (2011). Financial development, liberalization and technological deepening. European Economic Review, 55(5), 688-701. https://doi.org/10.1016/j.euroecorev.2010.09.004

Ang, J., \& Madsen, J. B. (2012). Risk capital, private credit, and innovative production. Canadian Journal of Economics, 45(4), 1608-1639. https://doi.org/10.1111/j.1540-5982.2012.01740.x

Archibugi, D., \& Filippetti, A. (2011) Is the economic crisis impairing convergence in innovation performance across Europe? Journal Common Market Studies, 49(6), 1153-1182. https://doi.org/10.1111/j.1468-5965.2011.02191.x

Archibugi, D., \& Filippetti, A. (2012). Innovation and economic crisis. Lessons and prospects from the economic crisis. Routledge. https://doi.org/10.4324/9780203804513

Archibugi, D., Filippetti, A., \& Frenz., M. (2013). The impact of the economic crisis on innovation: Evidence from Europe. Technological Forecasting \& Social Change, 80, 1247-1260. https://doi.org/10.1016/j.techfore.2013.05.005

Arellano, M., \& Bond, S. (1991). Some tests of specification for panel data: Monte Carlo evidence and an application to employment equations. The Review of Economic Studies, 58(2), 277-297. https://doi.org/10.2307/2297968

Arellano, M., \& Bover, O. (1995). Another look at the instrumental variable estimation of error-components models. Journal of Econometrics, 68(1), 29-51. https://doi.org/10.1016/0304-4076(94)01642-D

Barro, R. J., \& Sala-i-Martin, X. (2003). Economic growth (2 ${ }^{\text {nd }}$ ed.). MIT Press.

Besley, T., Roland, I., \& Van Reenen, J. (2018). The aggregate effects of credit market frictions: evidence from firm-level default assessments (Technical Report, mimeo).

Bond, S., Harhoff, D., \& Van Reenen, J. (1999). Investment, $R \& D$ and financial constraints in Britain and Germany (Working Paper \#W99/05, 45). Institute for Fiscal Studies.

https://doi.org/10.1920/wp.ifs.1999.9905 
Bond, S., Elston, J., Mairesse, J., \& Mulkay, B. (2003). Financial factors and investment in Belgium, France, Germany, and the United Kingdom: A comparison using company panel data. Review of Economics and Statistics, 85, 153-165. https://doi.org/10.1162/003465303762687776

Castellacci, F. (2008). Technology clubs, technology gaps and growth trajectories. Structural Change and Economic Dynamics, 19(4), 301-314. https://doi.org/10.1016/j.strueco.2008.07.002

Cozzens, S., \& Kaplinsky, R. (2009). Innovation, poverty and inequality: cause, coincidence, or coevolution? In Lundvall et al. (Eds.), Handbook of innovation systems and developing countries. Edward Elgar, UK. https://doi.org/10.4337/9781849803427.00009

Dedrick, J., Gurbaxani, V., \& Kraemer, K. L. (2003). Information technology and economic performance: a critical review of the empirical evidence. ACM Computing Surveys, 35, 1-28. https://doi.org/10.1145/641865.641866

Demirhan, D., \& Babacan, Ö. (2016). The role of financing in innovation ecosystems: a panel data analysis. Ege Stratejik Araştırmalar Dergisi, 7(Özel), 93-104. https://doi.org/10.18354/esam.71906

Dewan, S., \& Kraemer, K. L. (2000). Information technology and productivity: preliminary evidence from country-level data. Management Science, 46, 548-562. https://doi.org/10.1287/mnsc.46.4.548.12057

Dosi, G. (1988). Sources, procedures and microeconomic effects of innovation. Journal of Economic Literature, 26(3), 120-171.

Dosi, G. (1990). Finance, innovation and industrial change, Journal of Economic Behavior and Organization, 13, 299-319. https://doi.org/10.1016/0167-2681(90)90003-V

Dunning, J. H., \& Lundan, S. M. (2008). Institutions and the OLI paradigm of the multinational enterprise. Asia Pacific Journal of Management, 25(4), 573-593. https://doi.org/10.1007/s10490-007-9074-z

European Commission. (2010). Divergences within the euro area: Threat and opportunity. European Economy News: Magazine of the Directorate-General for Economic and Financial Affairs, 17, 8-9.

European Commission. (2017). 10 years since the start of the crisis: Back to recovery thanks to decisive EU action. https://ec.europa.eu/commission/presscorner/detail/en/IP_17_2401

European Commission. (2019). Innovation Union Scoreboard. https://ec.europa.eu/growth/content/2019innovation-scoreboards-innovation-performance-eu-and-its-regions-increasing_en

Fagerberg, J., Srholec, M., \& Knell, M. (2007). The competitiveness of nations: Why some countries prosper while others fall behind. World Development, 35(10), 1595-1620.

https://doi.org/10.1016/j.worlddev.2007.01.004

Filippetti, A., \& Archibugi, D. (2011). Innovation in times of crisis: national systems of innovation, structure, and demand, Research Policy, 40, 179-192. https://doi.org/10.1016/j.respol.2010.09.001

Fores, B., \& Camison, C. (2011). The complementary effect of internal learning capacity and absorptive capacity on performance: the mediating role of innovation capacity. International Journal of Technology Management, 55, 56-81. https://doi.org/10.1504/IJTM.2011.041680

Freeman, C. (1995). The 'National System of Innovation' in historical perspective. Cambridge Journal of Economics, 19(1), 5-24.

Freeman, C. (1987). Technology policy and economic performance: Lessons from Japan. Frances Pinter.

Furman, J., Porter, M., \& Stern, S. (2002). The determinants of national innovative capacity. Research Policy, 31, 899-933. https://doi.org/10.1016/S0048-7333(01)00152-4

Godin, B. (2009). National innovation system the system approach in historical perspective. Science, Technology and Human Values, 34(4), 476-501. https://doi.org/10.1177/0162243908329187

Gorodnichenko, Y., \& Schnitzer, M. (2013). Financial constraints and innovation: Why poor countries don't catch up. Journal of the European Economic Association, 11, 1115-1152.

https://doi.org/10.1111/jeea.12033 
Gorzelany-Dziadkowiec, M., Gorzelany, J., Stauskis, G., Hernik, J., Van Assche, K., \& Noszczyk, T. (2019). The innovation process in local development - the material, institutional, and intellectual infrastructure shaping and shaped by innovation. Technological and Economic Development of Economy, 25(6), 1232-1258. https://doi.org/10.3846/tede.2019.11094

Greenwood, J., Hercowitz, Z., \& Krusell, P. (1997). Long-run implications of investment specific-technological change. American Economic Review, 87, 342-362.

Günther, J., Kristalova, M., \& Ludwig, U. (2019). Structural stability of the research and development sector in European economies crisis despite the economic crisis. Journal of Evolutionary Economics, (29), 1415-1432. https://doi.org/10.1007/s00191-019-00640-Z

Hall, B. H., Mairesse, J., Branstetter, L., \& Crepon, B. (1999). Does cash flow cause investment and R\&D: An exploration using panel data for French, Japanese and United States Scientific Firms. In D. Audretsch \& A. R. Thurik (Eds.), Innovation, industry evolution and employment. Cambridge University Press. https://doi.org/10.2139/ssrn.105089

Hall, B. H. (2002). The financing of research and development. Oxford Review of Economic Policy, 18(1), 35-51. https://doi.org/10.1093/oxrep/18.1.35

Hall, B. H. (2008). The financing of innovation. In S. Shane (Ed.), Handbook of technology and innovation management (pp. 409-430). Blackwell Publishers.

Iammarino, S., Sanna-Randaccio, F., \& Savona, M. (2009). The perception of obstacles to innovation. Foreign multinationals and domestic firms in Italy. Revue déconomie industrielle, 125(1), 75-104. https://doi.org/10.4000/rei.3953

Jovanovic, B. (1997). Learning and growth. In D. Kreps \& K. Wallis (Eds.), Advances in economics and econometrics: Theory and applications (Vol. 2, pp. 318-339). Cambridge University Press. https://doi.org/10.1017/CCOL0521580129.009

Kamien, M., \& Schwartz, N. L. (1981). Dynamic optimization: The calculus of variations and optimal control in economics and management. Elsevier.

Kerr, W. R., \& Nanda, R. (2009). Democratizing entry: Banking deregulations, financing constraints, and entrepreneurship. Journal of Financial Economics, 94, 124-149.

https://doi.org/10.1016/j.jfineco.2008.12.003

King, R., \& Levine, R. (1993). Finance and growth: Schumpeter might be right. Quarterly Journal of Economics, 108, 717-737. https://doi.org/10.2307/2118406

Labra, R., \& Torrecillas, C. (2018). Estimating dynamic Panel data. A practical approach to perform long panels. Revista Colombiana de Estadística, 41(1), 31-52. https://doi.org/10.15446/rce.v41n1.61885

Labra, R., \& Torrecillas, C. (2014). Guía CERO para datos de panel. Un enfoque práctico. (UAM-Accenture Working Paper No. 2014/16, pp. 1-57). Univesidad Autonoma de Madrid.

Laeven, L., \& Valencia, F. (2013). The real effects of financial sector interventions during crises. Journal of Money, Credit and Banking, 45(1), 147-177. https://doi.org/10.1111/j.1538-4616.2012.00565.x

Lall, S. (1992). Technological capabilities and industrialization. World Development, 20(2), 165-186. https://doi.org/10.1016/0305-750X(92)90097-F

Lee, K., \& Kim, B. (2009). Both institutions and policies matter but differently for different income groups of countries: Determinants of long-run economic growth revisited. World Development, 37(3), 533-549. https://doi.org/10.1016/j.worlddev.2008.07.004

Lee, S. T., Gholami, R., \& Tong, T. Y. (2005). Time series analysis in the assessment of ICT impact at the aggregate level - Lessons and implications for the new economy. Information \& Management, 42, 1009-1022. https://doi.org/10.1016/j.im.2004.11.005

López, S. M., Molero, J., \& Santos-Arteaga, F. J. (2011). Poverty traps in a frictionless world: The effects of learning and technology assimilation. Structural Change and Economic Dynamics, 22, 106-115. https://doi.org/10.1016/j.strueco.2010.12.001 
Lorenz, E., \& Pommet, S. (2017). Innovation, credit constraints and national banking systems: A Comparison of developing nations (GREDEG Working Papers 2017-16). Groupe de REcherche en Droit, Economie, Gestion (GREDEG CNRS), University of Nice Sophia Antipolis.

Lundvall, B. A. (1992). National systems of innovation: toward a theory of innovation and interactive learning, Pinter Publishers.

Lundvall, B. Å. (2007). National innovation systems analytical concept and development tool. Industry and Innovation, 14(1), 95-119. https://doi.org/10.1080/13662710601130863

Lundvall, B. Å. (2016). The learning economy and the economics of hope. Anthem Press. https://doi.org/10.26530/OAPEN_626406

Manaresi, F., \& Pierri, N. (2017). Credit constraints and firm productivity: Evidence from Italy (Mo.Fi.R. Working Papers 137). https://doi.org/10.2139/ssrn.2906809

Mancusi, M. L., \& Vezzulli, A. (2014). R\&D and credit rationing in SMEs. Economic Inquiry, 52(3), 1153-1172. https://doi.org/10.1111/ecin.12080

Mazzucato, M. (2013). Financing innovation: Creative destruction vs. destructive creation. Industrial and Corporate Change, 22(4), 851-867. https://doi.org/10.1093/icc/dtt025

Mukoyama, T. (2003). Innovation, imitation and growth with cumulative technology, Journal of Monetary Economics, 50, 361-380. https://doi.org/10.1016/S0304-3932(03)00005-9

Mulkay, B., Hall, B. H., \& Mairesse, J. (2001). Investment and R\&D in France and in the United States. In Deutsche Bundesbank (Ed.), Investing today for the world of tomorrow. Springer Verlag. https://doi.org/10.1007/978-3-642-56601-1_19

O'Sullivan, M. (2005). Finance and innovation, in J. Fagerberg, D. C. Mowery, \& R. Nelson (Eds.), The Oxford handbook of innovation (pp. 240-265). Oxford University Press.

OECD. (2012, September 13). Innovation: Economic crisis and weak outlook hit R\&D, says OECD http:// www.oecd.org/newsroom/innovationeconomiccrisisandweakoutlookhitrdsaysoecd.htm

Oliner, S. D., \& Sichel, D. E. (1994). Computers and output growth revisited: How big is the puzzle? Brookings Papers on Economic Activity, 2, 273-317. https://doi.org/10.2307/2534658

Osei-Bryson, K. M., \& Ko, M. (2004). Exploring the relationship between information technology investments and firm performance using regression splines analysis. Information \& Management, 42, 1-13. https://doi.org/10.1016/j.im.2003.09.002

Pellegrino, G., \& Savona, M. (2017). No money, no honey? Financial versus knowledge and demand constraints to innovation. Research Policy, 46, 510-521. https://doi.org/10.1016/j.respol.2017.01.001

Perez, C. (2002). Technological revolutions and financial capital: The dynamics of bubbles and golden ages. Cheltenham, Elgar. https://doi.org/10.4337/9781781005323

Perez, C. (2004). Finance and technical change: a long-term view. In H. Hanusch, \& A. Pyka (Eds.), The elgar companion to neo-schumpeterian economics (pp. 775-799). Edward Elgar, Cheltenham.

Popov, A. (2017). Evidence on finance and economic growth (ECB Working Paper, 2115).

Roodman, D. (2012). XTABOND2: Stata module to extend xtabond dynamic panel data estimator. Statistical Software Components. Centre for Global Development, Washington, DC

Santos-Arteaga, F. J., Di Caprio, D., Tavana, M., \& O'Connor, A. (2017). Innovation dynamics and labor force restructuring with asymmetrically developed national innovation systems. International Business Review, 26, 36-56. https://doi.org/10.1016/j.ibusrev.2016.05.005

Savignac, F. (2008). Impact of financial constraints on innovation: What can be learned from a direct measure? Economics of Innovation and New Technology, 17(6), 553-569.

https://doi.org/10.1080/10438590701538432

Tylecote, A. (1994). Financial systems and innovation. In M. Dodgson \& R. Rothwell (Eds.), The handbook of industrial innovation (pp. 259-267). Edward Elgar. 
Van Tilburg, R. (2009). Finance for Innovation: Policy options for improving the financial component of the Dutch innovation system. Retrieved November 4, 2012, from http://www.awt.nl/upload/documents/publicaties/tekst/as36.pdf

Wälde, K. (1999). Optimal saving under Poisson uncertainty. Journal of Economic Theory, 87, 194-217. https://doi.org/10.1006/jeth.1999.2529

Witt, M. A., \& Lewin, A. Y. (2007). Outward foreign direct investment as escape response to home country institutional constraints. Journal of International Business Studies, 38(4), 579-594.

https://doi.org/10.1057/palgrave.jibs.8400285

\section{APPENDIX}

\section{Appendix A: Bellman equations}

\section{A.1. Theoretical framework}

The introduction of a set of Poisson processes in our stochastic growth setting follows the version of Ito's lemma employed by Wälde (1999). Let $\mathbf{z} \equiv\left(z_{1}, z_{2}\right)^{T}$ be a vector-valued Poisson process comprising two independent processes, $z_{1}$ and $z_{2}$. Let $f(\mathbf{x}) \equiv\left(f_{1}(\mathbf{x}), f_{2}(\mathbf{x})\right)^{T}$, $g(\mathbf{x})$ and $\sigma(\mathbf{x}) \equiv\left(\sigma_{1}(\mathbf{x}), \sigma_{2}(\mathbf{x})\right)^{T}$ be continuous real functions of $\mathbf{x} \equiv\left(x_{1}, x_{2}\right)$. Note that $f_{i}, g, \sigma_{i}: \mathfrak{R}^{2} \rightarrow \mathfrak{R}$.

Let $\mathbf{x}$ follow $d \mathbf{x}=f(\mathbf{x}) d t+\sigma(\mathbf{x}) d \mathbf{z}$, then $d g(\mathbf{x})$ is equal to

$$
\begin{aligned}
& d g(\mathbf{x})=\left[g_{x_{1}}(\mathbf{x}) f_{1}(\mathbf{x})+g_{x_{2}}(\mathbf{x}) f_{2}(\mathbf{x})\right] d t+ \\
& {\left[g\left(x_{1}+\sigma_{1}(\mathbf{x}), x_{2}\right)-g(\mathbf{x})\right] d z_{1}+\left[g\left(x_{1}, x_{2}+\sigma_{2}(\mathbf{x})\right)-g(\mathbf{x})\right] d z_{2} .}
\end{aligned}
$$

If $d z_{1}=d z_{2}=d z$, then $d g(\mathbf{x})$ equals

$$
d g(\mathbf{x})=\left[g_{x_{1}}(\mathbf{x}) f_{1}(\mathbf{x})+g_{x_{2}}(\mathbf{x}) f_{2}(\mathbf{x})\right] d t+\left[g\left(x_{1}+\sigma_{1}(\mathbf{x}), x_{2}+\sigma_{2}(\mathbf{x})\right)-g(\mathbf{x})\right] d z .
$$

Applying the differential generator Diff to $d g(\mathbf{x})$ we get

$$
\begin{aligned}
& \operatorname{Diff} g(\mathbf{x})=g_{x_{1}}(\mathbf{x}) f_{1}(\mathbf{x})+g_{x_{2}}(\mathbf{x}) f_{2}(\mathbf{x})+ \\
& {\left[g\left(x_{1}+\sigma_{1}(\mathbf{x}), x_{2}\right)-g(\mathbf{x})\right] a_{1}+\left[g\left(x_{1}, x_{2}+\sigma_{2}(\mathbf{x})\right)-g(\mathbf{x})\right] a_{2} .}
\end{aligned}
$$

where $a_{i} d t, i=1,2$, is the probability of $x_{i}$ jumping with an amplitude of $\sigma_{i}(\mathbf{x})$ and Diff $g(\mathbf{x})$ denotes the expected change of $g(\mathbf{x})$ per unit of time.

Assuming a unique Poisson process and applying Diff to $g(\mathbf{x})$ we get

$$
\text { Diff } g(\mathbf{x})=g_{x_{1}}(\mathbf{x}) f_{1}(\mathbf{x})+g_{x_{2}}(\mathbf{x}) f_{2}(\mathbf{x})+\left[g\left(x_{1}+\sigma_{1}(\mathbf{x}), x_{2}+\sigma_{2}(\mathbf{x})\right)-g(\mathbf{x})\right] a_{1} .
$$

\section{A.2. The optimization problem of countries}

Consider the increase in the productivity and asset value of the firm introducing an innovation

$$
\begin{gathered}
d\left(\frac{\xi}{\Gamma}\right)=\left(\Gamma-\frac{\xi}{\Gamma}\right) d z_{\xi}, \\
d v(\xi)=\left[\alpha_{v} v-v(\xi)\right] d z_{\xi} .
\end{gathered}
$$


Replace the variables in (A.4) as follows: $\mathbf{x}=\left(\frac{\xi}{\Gamma}, v(\xi)\right), f_{1}(\mathbf{x})=f_{2}(\mathbf{x})=0, g(\mathbf{x})=V(\mathbf{x})$, $\sigma_{1}(\mathbf{x})=\left(\Gamma-\frac{\xi}{\Gamma}\right), \sigma_{2}(\mathbf{x})=\alpha_{v} v-v(\xi)$ and $a_{1}=\theta_{\xi}$ to obtain

$$
E\left(\frac{d V\left(\frac{\xi}{\Gamma}, v(\xi)\right)}{d t}\right)=\theta_{\xi}\left[V\left(\frac{\xi}{\Gamma}+\left(\Gamma-\frac{\xi}{\Gamma}\right), v(\xi)+\alpha_{v} v-v(\xi)\right)-V\left(\frac{\xi}{\Gamma}, v(\xi)\right)\right]
$$

an expression that can be simplified to

$$
E\left(\frac{d V\left(\frac{\xi}{\Gamma}, v(\xi)\right)}{d t}\right)=\theta_{\xi}\left[V\left(\Gamma, \alpha_{v} v\right)-V\left(\frac{\xi}{\Gamma}, v(\xi)\right)\right]
$$

The expected dynamic evolution of the value function can be incorporated in the following Bellman equation to define the resulting stochastic optimization model (Kamien \& Schwartz, 1981)

$$
\rho V\left(\frac{\xi}{\Gamma}, v(\xi)\right)=\max _{n_{n}, n_{m}}\left[\pi\left(n_{m}\right)+E\left(\frac{d V\left(\frac{\xi}{\Gamma}, v(\xi)\right)}{d t}\right)\right],
$$

The optimization problem faced by each country is therefore given by

$$
\rho V\left(\frac{\xi}{\Gamma}, v(\xi)\right)=\max _{n_{n}, n_{m}}\left[\pi\left(n_{m}\right)+\theta_{\xi}\left[V\left(\Gamma, \alpha_{v} v\right)-V\left(\frac{\xi}{\Gamma}, v(\xi)\right)\right]\right] .
$$

\section{A.3. The optimization problem of consumers}

The value of the assets of a firm introducing an innovation in the innovator country, $v_{n} a_{n}^{m}$, evolves as follows

$$
d\left(v_{n} a_{n}^{m}\right)=\left[v a_{n}^{n}+\frac{v a_{m \mid n}^{m}}{2}-v_{n} a_{n}^{m}-v_{m} a_{m}^{m}\right] d t+\left[\alpha_{v} v a_{n}^{m}-v_{n} a_{n}^{m}\right] d z_{n},
$$

while the assets of a firm introducing an innovation in the laggard country, $\frac{v_{m} a_{m}^{m}}{2}$, evolve according to

$$
d\left(\frac{v_{m} a_{m}^{m}}{2}\right)=\left[v a_{n}^{n}+\frac{v a_{m \mid n}^{m}}{2}-v_{n} a_{n}^{m}-v_{m} a_{m}^{m}\right] d t+\left[\frac{\alpha_{v} v a_{m}^{m}}{2}-\frac{v_{m} a_{m}^{m}}{2}\right] d z_{m} .
$$

The evolution of the expected income of consumers is given by

$$
E[v a]=\mu_{n}\left(\theta_{n}\right) v_{n} a_{n}^{m}+\mu_{m}\left(\theta_{m}\right) \frac{v_{m} a_{m}^{m}}{2} .
$$


The differential $d g(\mathbf{x})$ defined in (A.1) describes the stochastic evolution of $E[v a]$ after replacing the corresponding variables as follows

$$
\begin{aligned}
& \mathbf{x}=\left(v_{n} a_{n}^{m}, \frac{v_{m} a_{m}^{m}}{2}\right), \\
& f_{1}(\mathbf{x})=f_{2}(\mathbf{x})=\left[v a_{n}^{n}+\frac{v a_{m \mid n}^{m}}{2}-v_{n} a_{n}^{m}-v_{m} a_{m}^{m}\right], \\
& g(\mathbf{x})=\mu_{n}\left(\theta_{n}\right) v_{n} a_{n}^{m}+\mu_{m}\left(\theta_{m}\right) \frac{v_{m} a_{m}^{m}}{2}, \\
& \sigma_{1}(\mathbf{x})=\left[\alpha_{v} v a_{n}^{m}-v_{n} a_{n}^{m}\right], \\
& \sigma_{2}(\mathbf{x})=\left[\frac{\alpha_{v} v a_{m}^{m}}{2}-\frac{v_{m} a_{m}^{m}}{2}\right], \\
& d z_{1}=d z_{n}, \\
& d z_{2}=d z_{m} .
\end{aligned}
$$

The evolution of $E[\mathrm{va}]$ is therefore given by

$$
\begin{aligned}
& d\left(\mu_{n}\left(\theta_{n}\right) v_{n} a_{n}^{m}+\mu_{m}\left(\theta_{m}\right) \frac{v_{m} a_{m}^{m}}{2}\right)= \\
& {\left[v a_{n}^{n}+\frac{v a_{m \mid n}^{m}}{2}-v_{n} a_{n}^{m}-v_{m} a_{m}^{m}\right] d t+} \\
& {\left[\left(\mu_{n}\left(\theta_{n}\right)\left(v_{n} a_{n}^{m}+\left[\alpha_{v} v a_{n}^{m}-v_{n} a_{n}^{m}\right]\right)+\mu_{m}\left(\theta_{m}\right) \frac{v_{m} a_{m}^{m}}{2}\right)-\right.} \\
& \left.\left(\mu_{n}\left(\theta_{n}\right) v_{n} a_{n}^{m}+\mu_{m}\left(\theta_{m}\right) \frac{v_{m} a_{m}^{m}}{2}\right)\right] d z_{n}+ \\
& {\left[\left(\mu_{n}\left(\theta_{n}\right) v_{n} a_{n}^{m}+\mu_{m}\left(\theta_{m}\right)\left(\frac{v_{m} a_{m}^{m}}{2}+\left[\frac{\alpha_{v} v a_{m}^{m}}{2}-\frac{v_{m} a_{m}^{m}}{2}\right]\right)-\right.\right.} \\
& \left.\left(\mu_{n}\left(\theta_{n}\right) v_{n} a_{n}^{m}+\mu_{m}\left(\theta_{m}\right) \frac{v_{m} a_{m}^{m}}{2}\right)\right] d z_{m},
\end{aligned}
$$

which can be simplified to

$$
\begin{aligned}
& d\left(\mu_{n}\left(\theta_{n}\right) v_{n} a_{n}^{m}+\mu_{m}\left(\theta_{m}\right) \frac{v_{m} a_{m}^{m}}{2}\right)=\left[v a_{n}^{n}+\frac{v a_{m \mid n}^{m}}{2}-v_{n} a_{n}^{m}-v_{m} a_{m}^{m}\right] d t+ \\
& {\left[\mu_{n}\left(\theta_{n}\right)\left[\alpha_{v} v a_{n}^{m}-v_{n} a_{n}^{m}\right]\right] d z_{n}+\left[\mu_{m}\left(\theta_{m}\right)\left(\frac{\alpha_{v} v a_{m}^{m}}{2}-\frac{v_{m} a_{m}^{m}}{2}\right)\right] d z_{m},}
\end{aligned}
$$


Equations (A.16) and (A.3) can be used to derive the Bellman equation that describes the optimization problem of consumers after replacing the corresponding variables as follows

$$
\begin{aligned}
& \mathbf{x}=E(v a) \\
& f_{1}(\mathbf{x})=\left[v a_{n}^{n}+\frac{v a_{m \mid n}^{m}}{2}-v_{n} a_{n}^{m}-v_{m} a_{m}^{m}\right], \\
& f_{2}(\mathbf{x})=0 \\
& g(\mathbf{x})=V(E(v a)), \\
& \sigma_{1}(\mathbf{x})=\left[\mu_{n}\left(\theta_{n}\right)\left[\alpha_{v} v a_{n}^{m}-v_{n} a_{n}^{m}\right]\right], \\
& \sigma_{2}(\mathbf{x})=\left[\mu_{m}\left(\theta_{m}\right)\left(\frac{\alpha_{v} v a_{m}^{m}}{2}-\frac{v_{m} a_{m}^{m}}{2}\right)\right], \\
& a_{1}=\theta_{n}, \\
& a_{2}=\theta_{m}
\end{aligned}
$$

leading to

$$
\begin{aligned}
& E\left(\frac{d V(E(v a))}{d t}\right)= \\
& V_{E(v a)}[E(v a)]\left[v a_{n}^{n}+\frac{v a_{m \mid n}^{m}}{2}-v_{n} a_{n}^{m}-v_{m} a_{m}^{m}\right]+ \\
& \theta_{n}\left[V\left[E(v a)+\mu_{n}\left(\theta_{n}\right)\left[\alpha_{v} v a_{n}^{m}-v_{n} a_{n}^{m}\right]\right]-V[E(v a)]\right]+ \\
& \theta_{m}\left[V\left[E(v a)+\mu_{m}\left(\theta_{m}\right)\left[\frac{\alpha_{v} v a_{m}^{m}}{2}-\frac{v_{m} a_{m}^{m}}{2}\right]\right]-V[E(v a)]\right.
\end{aligned}
$$

which is equivalent to

$$
\begin{aligned}
& E\left(\frac{d V(E(v a))}{d t}\right)= \\
& V_{E(v a)}[E(v a)]\left[v a_{n}^{n}+\frac{v a_{m \mid n}^{m}}{2}-v_{n} a_{n}^{m}-v_{m} a_{m}^{m}\right]+ \\
& \theta_{n}\left[V\left[\mu_{n}\left(\theta_{n}\right)\left[v_{n} a_{n}^{m}+\alpha_{v} v a_{n}^{m}-v_{n} a_{n}^{m}\right]+\mu_{m}\left(\theta_{m}\right) \frac{v_{m} a_{m}^{m}}{2}\right]-V\left[\mu_{n}\left(\theta_{n}\right) v_{n} a_{n}^{m}+\mu_{m}\left(\theta_{m}\right) \frac{v_{m} a_{m}^{m}}{2}\right]\right]+ \\
& \theta_{m}\left[V\left[\mu_{n}\left(\theta_{n}\right) v_{n} a_{n}^{m}+\mu_{m}\left(\theta_{m}\right)\left[\frac{v_{m} a_{m}^{m}}{2}+\frac{\alpha_{v} v a_{m}^{m}}{2}-\frac{v_{m} a_{m}^{m}}{2}\right]\right]-V\left[\mu_{n}\left(\theta_{n}\right) v_{n} a_{n}^{m}+\mu_{m}\left(\theta_{m}\right) \frac{v_{m} a_{m}^{m}}{2}\right]\right]
\end{aligned}
$$


Equation (A.19) can now be incorporated into the Bellman equation defining the optimization problem of consumers based on their expected evolution of the system

$$
\rho V(E(v a))=\max _{a_{n}^{m}, a_{m}^{m}}\left[u(c)+E\left(\frac{d V(E(v a))}{d t}\right)\right],
$$

where $u(c)$ denotes the utility derived from the consumption of the latest most advanced product, and

$$
\begin{aligned}
& E\left(\frac{d V[E(v a)]}{d t}\right)= \\
& V_{E(v a)}[E(v a)]\left[v a_{n}^{n}+\frac{v a_{m \mid n}^{m}}{2}-v_{n} a_{n}^{m}-v_{m} a_{m}^{m}\right]+ \\
& \theta_{n}\left[V\left[\mu_{n}\left(\theta_{n}\right)\left(\alpha_{v} v a_{n}^{m}\right)+\mu_{m}\left(\theta_{m}\right) \frac{v_{m} a_{m}^{m}}{2}\right]-V\left[\mu_{n}\left(\theta_{n}\right) v_{n} a_{n}^{m}+\mu_{m}\left(\theta_{m}\right) \frac{v_{m} a_{m}^{m}}{2}\right]\right]+ \\
& \theta_{m}\left[V\left[\mu_{n}\left(\theta_{n}\right) v_{n} a_{n}^{m}+\mu_{m}\left(\theta_{m}\right)\left(\frac{\alpha_{v} v a_{m}^{m}}{2}\right)\right]-V\left[\mu_{n}\left(\theta_{n}\right) v_{n} a_{n}^{m}+\mu_{m}\left(\theta_{m}\right) \frac{v_{m} a_{m}^{m}}{2}\right]\right] .
\end{aligned}
$$

\section{Appendix B: Upper innovators and laggard}

Table B1. Technological classification of countries

\begin{tabular}{|l|l|}
\hline \multicolumn{1}{|c|}{ Upper innovators } & \multicolumn{1}{c|}{ Laggards } \\
\hline Austria & Bulgaria \\
\hline Belgium & Croatia \\
\hline Denmark & Cyprus \\
\hline Finland & Czech Republic \\
\hline France & Estonia \\
\hline Germany & Greece \\
\hline Ireland & Hungary \\
\hline Luxembourg & Italy \\
\hline Netherlands & Latvia \\
\hline Slovenia & Lithuania \\
\hline Sweden & Malta \\
\hline United Kingdom & Poland \\
\hline & Portugal \\
\hline & Romania \\
\hline & Slovakia \\
\hline & Spain \\
\hline
\end{tabular}




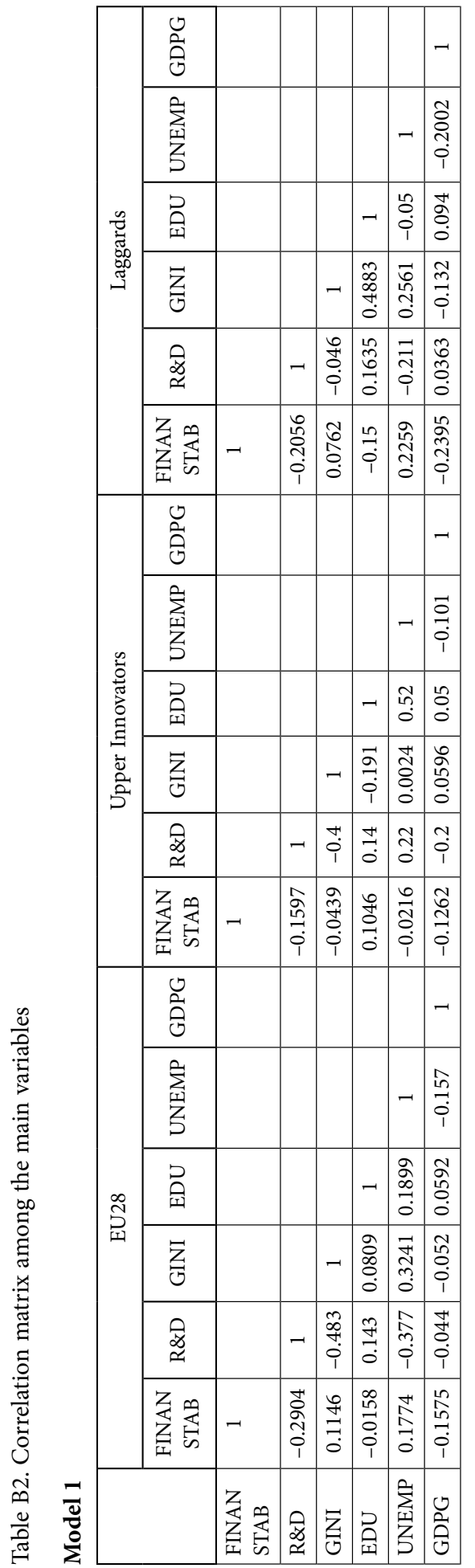

\begin{tabular}{|c|c|c|c|c|c|c|c|}
\hline \multirow{6}{*}{ 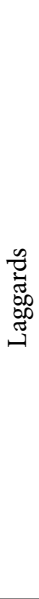 } & $\begin{array}{l}0 \\
\text { லે }\end{array}$ & & & & & & $\neg$ \\
\hline & 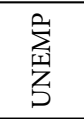 & & & & & - & $\begin{array}{l}\overrightarrow{0} \\
0 \\
-1 \\
1 \\
1\end{array}$ \\
\hline & 只 & & & & - & $\stackrel{2}{3}$ & $\begin{array}{l}\text { No } \\
\text { O̦ } \\
0\end{array}$ \\
\hline & Ö & & & $\rightarrow$ & $\stackrel{\infty}{\stackrel{\infty}{二}}$ & \begin{tabular}{l}
$\hat{6}$ \\
\multirow{1}{*}{} \\
0 \\
0
\end{tabular} & $\begin{array}{l}\infty \\
0 \\
0 \\
0 \\
0 \\
1\end{array}$ \\
\hline & 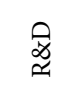 & & - & $\begin{array}{l}8 \\
0 \\
0 \\
0 \\
0\end{array}$ & $\begin{array}{l}20 \\
\infty \\
0 \\
0 \\
0\end{array}$ & 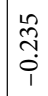 & $\begin{array}{l}m \\
0 \\
0 \\
0\end{array}$ \\
\hline & 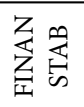 & - & 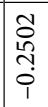 & 范 & $\begin{array}{l}\infty \\
\infty \\
0 \\
0 \\
0 \\
0 \\
1\end{array}$ & $\begin{array}{l}\stackrel{0}{\circ} \\
\stackrel{0}{0} \\
0\end{array}$ & 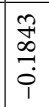 \\
\hline \multirow{6}{*}{ 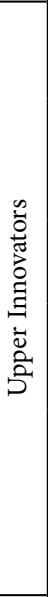 } & $\begin{array}{l}0 \\
0 \\
0\end{array}$ & & & & & & $\neg$ \\
\hline & 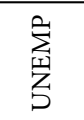 & & & & & - & $\begin{array}{l}\infty \\
0 \\
0 \\
0 \\
0\end{array}$ \\
\hline & 号 & & & & - & ఫ़े & ڤọ \\
\hline & نં & & & -7 & $\overrightarrow{0}$ & $\begin{array}{c}\tilde{N} \\
\tilde{n} \\
0\end{array}$ & $\begin{array}{c}1 \\
10 \\
0 \\
0 \\
1\end{array}$ \\
\hline & ఫે & & - & $\hat{0}$ & Oे. & กิ & ָै. \\
\hline & 党离 & - & 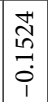 & $\begin{array}{l}0 \\
\infty \\
\infty \\
0 \\
0 \\
1 \\
1\end{array}$ & 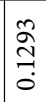 & 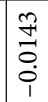 & \begin{tabular}{l}
0 \\
$\stackrel{0}{1}$ \\
\hdashline \\
0 \\
1
\end{tabular} \\
\hline \multirow{6}{*}{ 足 } & $\begin{array}{l}0 \\
0 \\
01 \\
01\end{array}$ & & & & & & $\neg$ \\
\hline & 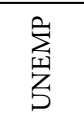 & & & & & - & 芳 \\
\hline & 只 & & & & $\neg$ & $\begin{array}{l}\stackrel{2}{2} \\
\stackrel{0}{0} \\
\end{array}$ & $\begin{array}{l}1 \\
0 \\
\swarrow 0 \\
0 \\
0 \\
0\end{array}$ \\
\hline & Ö & & & -1 & $\begin{array}{l}\tilde{1} \\
\tilde{2} \\
0 \\
0 \\
0\end{array}$ & 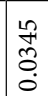 & $\begin{array}{l}\hat{\alpha} \\
\dot{0} \\
0 \\
0\end{array}$ \\
\hline & $\underset{\mathscr{z}}{\mathscr{\simeq}}$ & & - & $\begin{array}{l}\vec{\infty} \\
0 \\
0 \\
0\end{array}$ & $\stackrel{+}{\stackrel{+}{1}}$ & $\begin{array}{l}\vec{\infty} \\
\tilde{n} \\
0 \\
i\end{array}$ & $\begin{array}{l}1 \\
0 \\
0 \\
0 \\
1 \\
1\end{array}$ \\
\hline & 党离 & $\neg$ & $\begin{array}{l}\infty \\
\sigma \\
m \\
0 \\
1\end{array}$ & $\begin{array}{l}+1 \\
\sigma \\
\vdots \\
\\
1\end{array}$ & $\begin{array}{l}\tilde{N} \\
\tilde{\sigma} \\
0 \\
0 \\
1\end{array}$ & 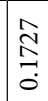 & 勇 \\
\hline & & 至学 & 字 & ن̊ & 号 & 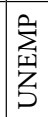 & ט \\
\hline
\end{tabular}

